\title{
Application of high-resolution remote sensing technology for the iron ore deposits of the West Kunlun Mountains in China
} \author{
Shaopeng Zhang ${ }^{1,2}$ and Wenbo Wang ${ }^{1}$ \\ ${ }^{1}$ Geological Exploration Institute of Aerial Photogrammetry and Remote Sensing Bureau, Xi'an,710199 China; \\ (*corresponding author: 170269854@qq.com / wanghui.rock@163.com) \\ 2 Yulin University, School of Management, Yulin, 719000 China \\ ${ }^{3}$ Chang'an University, School of Earth Science and Land and Resources, Xi'an, 710054 China \\ ${ }^{4}$ Inner Mongolia Mining Exploitation CO.LTD, Hohhot, 010051 China
}

Yuhai Fan ${ }^{1,2,3, *}$, Hui Wang ${ }^{1, *}$, Xingke Yang ${ }^{3}$, Guofeng Zhang ${ }^{4}$, Zhaoyang Li ${ }^{1}$, Furong Tan ${ }^{1}$,

doi: $10.4154 / g c .2021 .03$

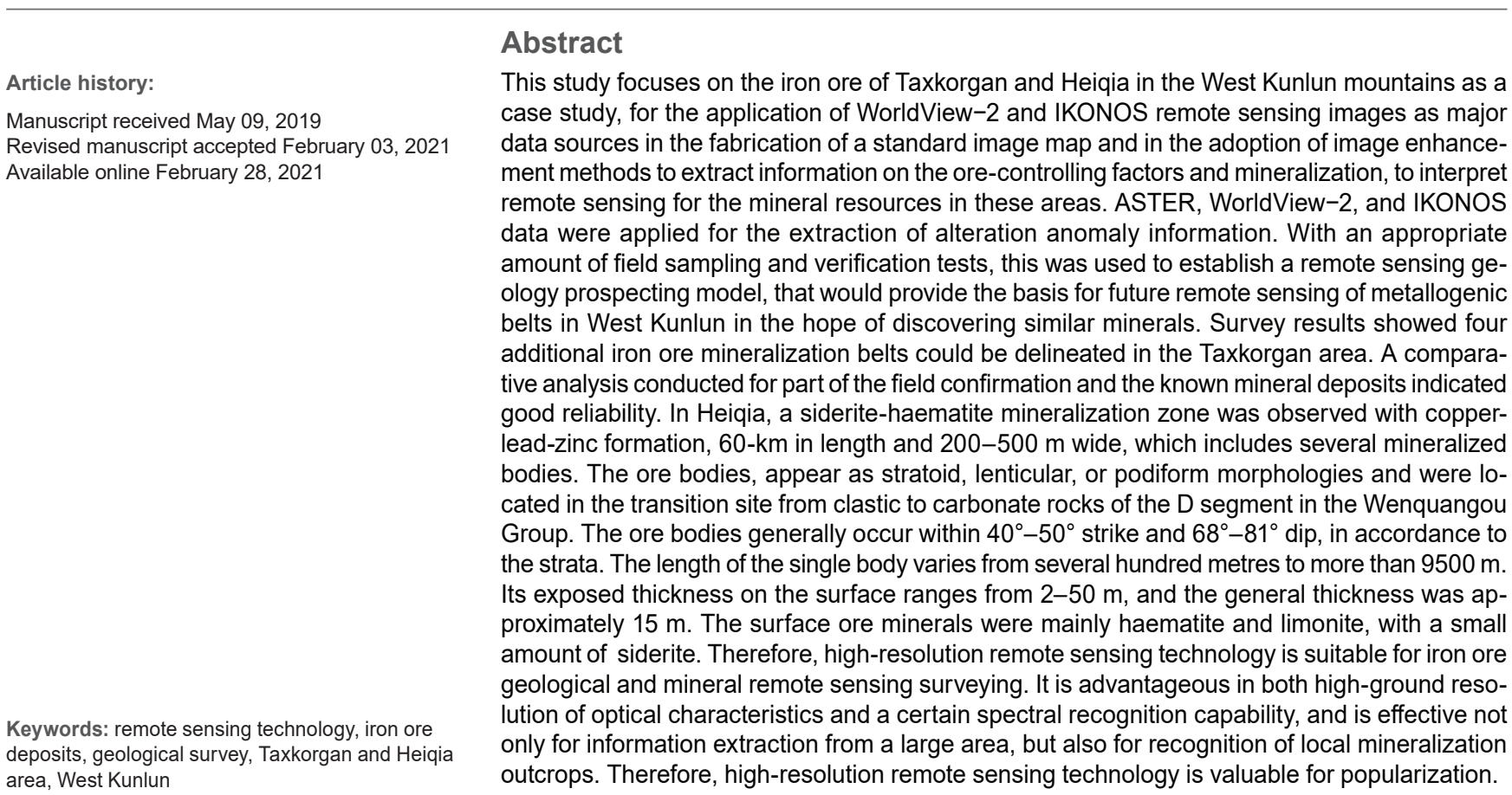

\section{INTRODUCTION}

Remote sensing is an emerging technology discipline that began with the successful launch of the Multispectral Scanner (MSS) on the United States' Landsat (LANDSAT) in 1972 (WANG et al., 2011; ALIJAGIĆ \& ŠAJN, 2020). Since then, coupled with the continuous development of space remote sensing and satellite sensor technology in recent years, a variety of high-resolution and improved remote sensing data has emerged both locally as well as globally. For instance, Worldview-2 (SHANG, 2009) and Quickbird have both reached metre-level resolution, while Worldview-3, launched in 2014, has achieved 0.3-m resolution and a broader spectral range. Moreover, China's launch of highresolution remote sensing satellites, such as GF_1, GF_2, Resource 2, Resource 3, Tiantu 1, and Tiantu 2, has pushed the technology and its applications to new heights, including use in the detection of mineral deposits (CHEN et al., 2012; ZHANG et al., 2015; YANG \& ZHAO, 2015). Geological deposits contain different mineral and chemical compositions to their surrounding rocks, and these differences are often reflected in remote sensing images in the form of spectral anomaly information. In this regard, a series of remote sensing digital image processes becomes an effective, prospective means of acquiring the geological anomaly information related closely to ore-bearing strata, mineralized alteration zones, contact metamorphic zones, and tectonic zones (SHANG, 2009; WANG et al., 2011; CHEN et al., 2012; JIN et al., 2014; ZHANG et al., 2015; YANG \& ZHAO, 2015; HOWARI et al., 2019; FAN et al., 2021).

Located at the junction of the Palaeo-Asian and Tethyan tectonic domains, West Kunlun is an important part of the Qin-QiKun tectonic belt of China, and also serves as an important area for studying the evolution of the Tethyan Ocean (PAN,1989, 1994, 1999; JIANG \& ZHU, 1992; CHENG, 1994; JIANG \& ZHU, 1992, 2002; YANG, 1994; PAN et al., 1995; PAN et al., 1996; CUI et al., 2006; WU et al., 2008; WANG et al., 2013; LI et al, 2011. LI, 2015; MENG et al., 2019). West Kunlun is characterized by strata exposed from Palaeoproterozoic to Mesozoic age (WANG H et al., 2016; ZHAO et al., 2010), by strong folds and faults (WU et al., 2008), and by the experience of multistage and various types of tectonic events (LU et al., 2003; YANG et al., 2004; XU et al., 2004; LI et al., 2008), or geological events in different periods that are superimposed on each other, such as multistage magmatism and multistage metamorphism with complex mag- 
matic (GAO et al., 2013; ZHAO \& LIU, 2014; KANG et al., 2015; YUN et al., 2015), sedimentary (YAO et al., 2006; LI et al., 2007; ZONG et al., 2010), and metamorphic formations (JIANG et al., 1992; PAN, 1994; YANG, 1994; LI et al., 2008, 2011). Thus, the strata, structure, metamorphism, magmatic activity, and other metallogenic geological conditions in the area are clear, with different types of deposits being discovered, together with good mineral prospects (BUREAU OF GEOLOGY AND MINERAL RESOURCES OF XINJIANG, 1993; SUN et al., 1997; JIA, 1999; WANG et al., 2000; DONG et al., 2003; XI'AN INSTITUTE OF GEOLOGY AND MINERAL RESOURCES, 2006; WANG et al., 2006; CHEN et al., 2007; HOU et al., 2008). Despite such advantages, West Kunlun remains an area with the lowest degree of geological and mineral research of China's orogenic belt, due mainly to its cold and anoxic climate, strong topographic dissection, steep terrain, sparse population, and inconvenient transport network (YANG, 1994; LI et al., 2011, LI, 2015). Nonetheless, its sparse vegetation and exposed bedrock make it a suitable target for the development of high-resolution remote sensing technology (WANG et al., 2011; CHEN et al., 2012; JIN et al., 2014; YANG \& ZHAO, 2015).

An important mineral for economic development is iron ore, formed through various processes including sedimentary metamorphism, magma, contact metasomatism-hydrothermal, volcanism, sedimentary deposition, and weathering (GARAŠIĆ \& JURKOVIĆ, 2012; JURKOVIĆ \& HRVATOVIĆ, 2014; JELENKOVIĆ, 2016; WANG et al., 2018). West Kunlun's iron polymetallic ore belt includes features of a large number of deposits, large-scale, and associated polymetallic mineralization that have attracted geological research both locally and internationally (FENG et al., 2011; QIAO et al., 2015, 2016; WANG H., 2016; LI et al., 2010). After years of field work, the present author has dis- covered magnetite deposits, such as Laohe and Zankan, in the Bulunkuole group of the Palaeoproterozoic in the Taxkorgan area, along with the haematite-pinerite containing copper, lead, and zinc, in the Wenquangou group of Lower Silurian age in the Heiqia area (WANG H., 2016). The iron ore of Taxkorgan and Heiqia in the mountains of West Kunlun is used herein as a case study and a major data source for WorldView-2 and IKONOS remote sensing images, in the fabrication of a standard image map and adoption of methods of image enhancement so as to extract information on ore-controlling factors and mineralization via interpretation of the remotely-sensed mineral resources. Data provided by ASTER, WorldView-2, and IKONOS are exploited for the extraction of alteration anomaly information. A remote sensing geology prospecting model is established with an appropriate amount of field sampling and a verification test, to provide the basis for future remote sensing on the metallogenic belt of West Kunlun, in the prospect of discovering similar mineral deposits.

\section{GEOLOGICAL FRAMEWORK}

The study area spans the mountains of Kunlun and Karakorum, at the junction of the Palaeo-Asian and Tethys tectonic (Kunnan-Yubei suture zone) domains; geographical coordinates E75 ${ }^{\circ} 5^{\prime}-79^{\circ} 15^{\prime}$, N35 $30^{\circ}-37^{\circ} 40^{\prime}$ ' (LI et al., 2013; WANG et al., 2015; LIU et al., 2015; QIN et al., 2018; HOU et al., 2018; YANG, 1994; PAN et al., 1996; WU et al., 2008).

The metallogenic belts are III-1-(1) Moustag-Aksai Chin (Terrigenous Basin) $\mathrm{Fe}-\mathrm{Cu}-\mathrm{Au}-\mathrm{Pb}-\mathrm{Zn}-\mathrm{RM}$ Metallogenic belt, and III-2-(1) Big Hong Liutan (Terrigenous active zone) $\mathrm{Fe}-\mathrm{RM}-\mathrm{Fe}-\mathrm{Pb}-\mathrm{Zn}-\mathrm{Cu}$ Metallogenic belt (PAN, 1999; LI, 2015; SUN et al., 1997; BUREAU OF GEOLOGY AND MINERAL RESOURCES OF XINJIANG, 1993; DONG et al., 2003; JIA, 1999; WANG et al., 2000) (Fig. 1).

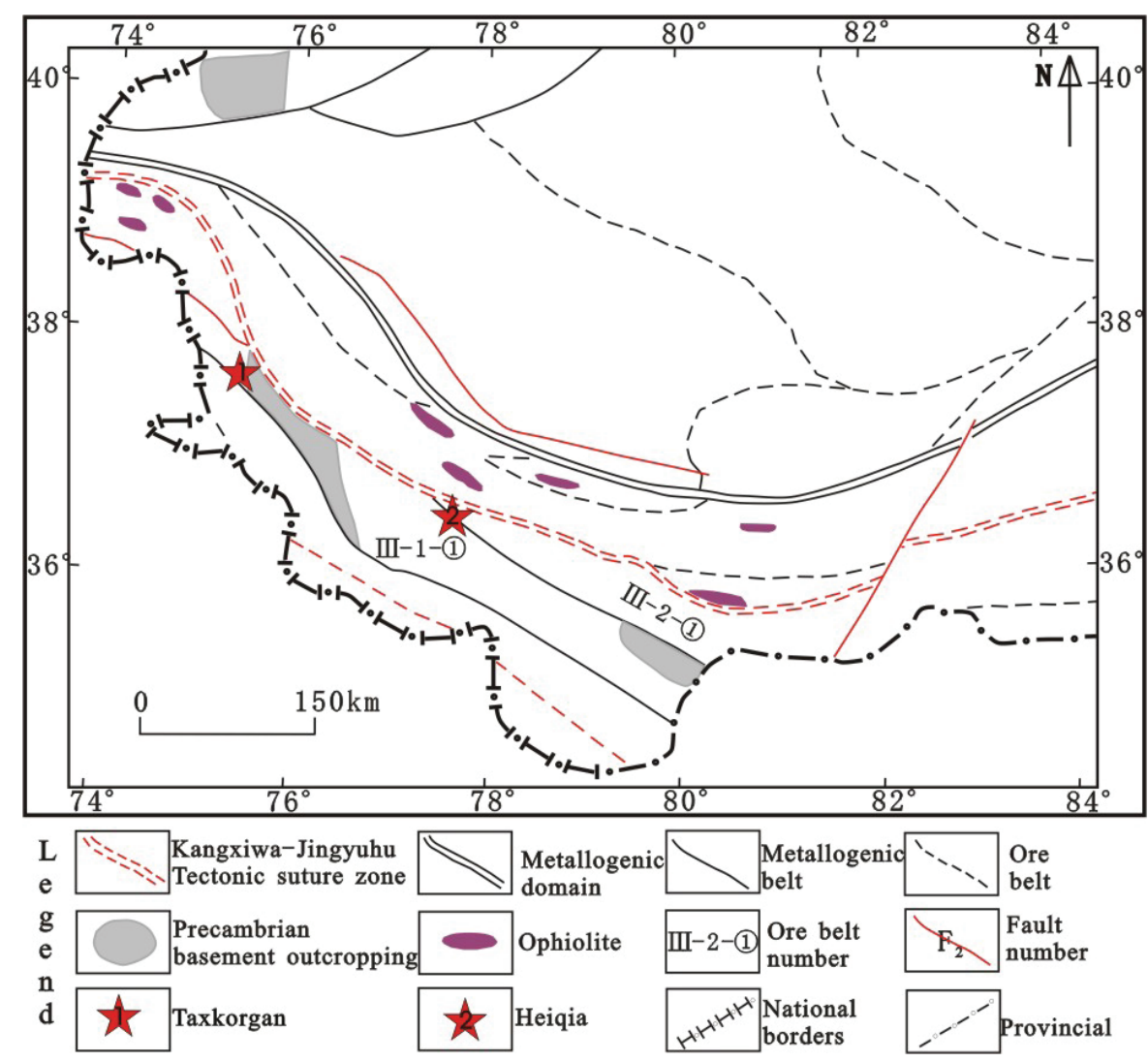

Figure 1. Divisional map of the metallogenic belt in the study area. Metallogenic belts: III-1-1)Moustag-Aksai Chin (Terrigenous Basin) Fe-Cu-Au-Pb$\mathrm{Zn}-\mathrm{RM}$ metallogenic belt; III-2-(1) Big Hong Liutan (Terrigenous active zone) Fe-RM-Fe-Pb-Zn-Cu metallogenic belt. 


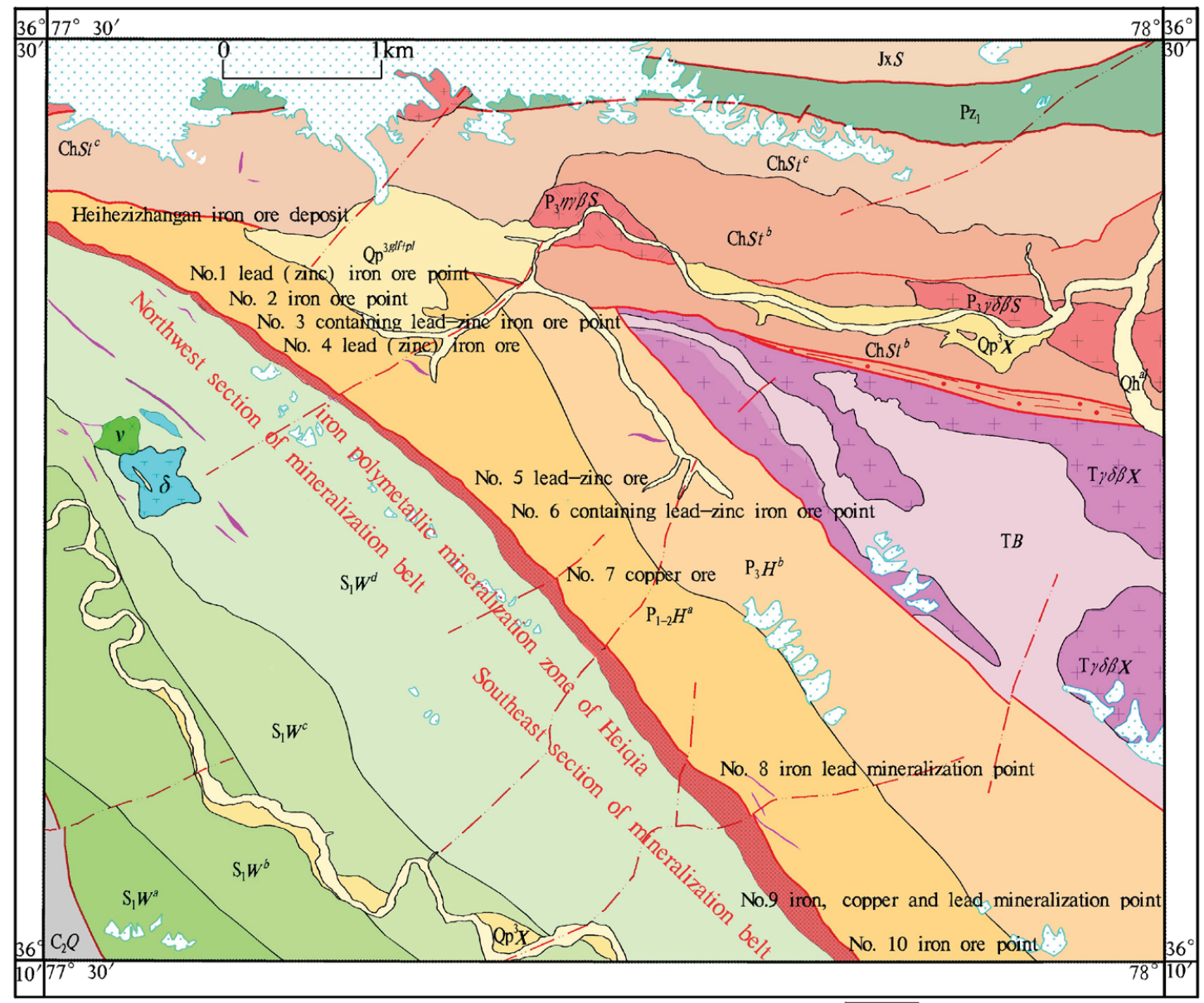

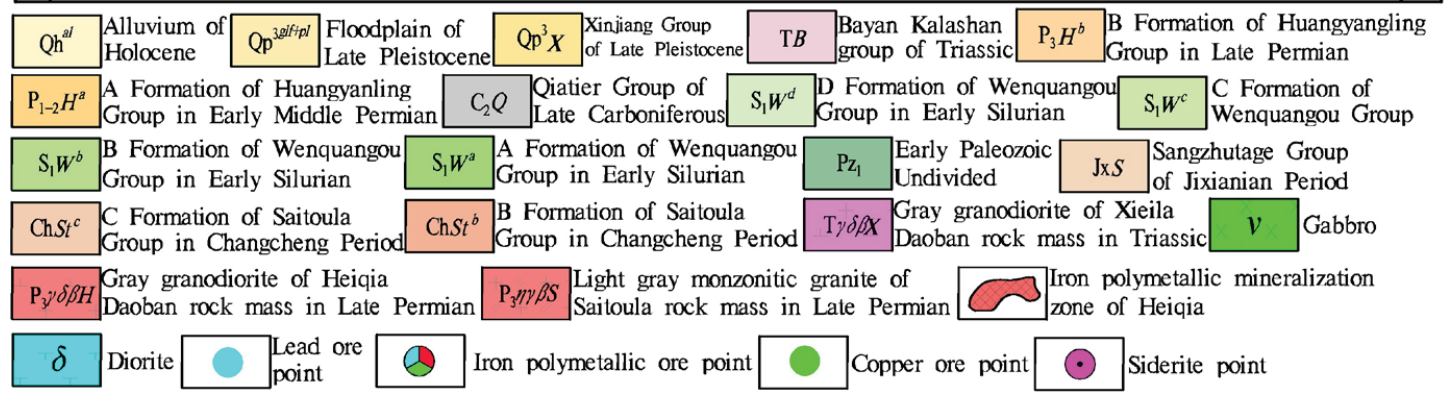

Figure 2. The distribution of typical ore deposits and ore (chemical) locations of the Heiqia polymetallic mineralization zone.

\subsection{Geological characteristics of iron deposits of the Taxkorgan area}

The Taxkorgan area is bounded by the Kangxiwa-MuzitageAnimaqing Late Palaeozoic junction belt, with the Upper Carboniferous (undivided) in the north, with a sporadic distribution of Ordovician-Silurian, and the widely exposed Palaeoproterozoic Brungula Group in the south. The contact relationships between different strata are tectonic. Magmatic activity is very strong and an intermediate-acid rock mass is widely distributed north of the junction zone. Similarly, south of the junction zone, magmatic activity is frequent although there is less distribution of the intermediate-acid rock mass. Relatively, there are strong folds and faults in the area, accompanied by an overall structural orientation to the NW. The strata exposed in this area mainly belong to a ferrosilicon formation of high green schist facies of the Blenkole Group in the Palaeoproterozoic, distributed mainly in the in NW and SEE directions, and mostly in fault contact with the surrounding strata.
Metallogenic geological background: The study area was located in the Taxkorgan landmass, with the junction zones of Taasi-Sekblak and Kangxiwa-Wacha as north and south boundaries, respectively. The outcropping strata belong to the Brungula Group of Palaeoproterozoic age $\left(\mathrm{Pt}_{1} B\right)$. Faults and folds were well developed in the area. The dominant structural orientation was NW, consistent with the strike of the north-south boundary faults. Magmatic activity existed from the Proterozoic-to-Himalayan tectonic movement. Ultrabasic to acidic magmatic rocks were exposed, of which intermediate-acidic granite and granodiorite were dominant during the Yanshanian tectonic movements (YAN et al., 2012; WAND, J.F. ,2013; WANG et al., 2013; WANG et al., 2017).

Mining stratum: Magnetite was localized in the iron-bearing section of the Brongol Group $\left(\mathrm{Pt}_{1} B\right)$. The main lithology was (iron-stained) biotite quartz schist, followed by (including magnetite?) gneiss with hornblende and biotite, magnetite quartz schist, two mica quartz schist, sericite quartz schist with magne- 
tite, a small number of oblique long-angle flash schist (gneiss), chlorite schist, and marble (WANG, et al., 2013; WANG et al., 2017).

Ore body characteristics: Most magnetite ores were ferrous black and gray-black, irregular (thick, massive, layered and lenticular) bodies. The occurrence of the ore bodies was similar to those of the roof and floor wall rocks, striking NW-SE and dipping NE. The surface was layered, banded, and irregularly distributed. The lithology of the roof was mostly (iron-stained) black cloud quartz schist (WANG et al., 2013; WANG et al., 2017).

Wall rock alteration: The altered minerals of the wall rocks were mainly recrystallization of carbonates, actinolitization, chloritization, sericitization, limonitization / magnetitization, and so on (WANG et al., 2013; WANG et al., 2017).

Ore characteristics: The ore texture was mainly allotriomorphic to hipidiomorphic, idiomorphic to hipidiomorphic, cyclopean granular, lepidoblastic, and cataclastic, whereas its structure was mainly disseminated, massive, and banded. Ore minerals in the area mainly include magnetite, haematite, pyrite, and limonite (WANG et al., 2017).

Ore grade: The average ore grade was TFe 37.3\%-58.69\%, $\mathrm{SiO}_{2} 10.33 \%-30.27 \%, \mathrm{~S}<0.08 \%, \mathrm{P}_{2} \mathrm{O}_{5}<0.21 \%$. Black magnetite was often accompanied by rare elements, such as vanadium and titanium (WANG et al., 2017).

\subsection{Geological characteristics of iron-polymetallic mineralization belt of Heiqia}

The iron-polymetallic mineralization belt of Heiqia is located in the D Formation of the Wenquangou Group of Early Silurian age $\left(\mathrm{S}_{1} W^{\mathrm{d}}\right)$, whereas its northeast side is a Formation of the Huangyanling Group from the Early Middle Permian $\left(\mathrm{PH}^{\mathrm{a}}\right)$ along the Karatag fault boundary. The lithology of $\mathrm{S}_{1} W^{\mathrm{d}}$ is composed mainly of cinerous-gray sandy slate with argillaceous slate and metamorphic sandstone; the top contains several layers of carbonate rocks, such as dolomite, iron dolomite, silicified dolomite, and a small amount of limestone (locally marbled) with siderite. In contrast, the lithology of $\mathrm{P} H^{\mathrm{a}}$ is characterized by gray-black carbonaceous slate or spotted (pyrite-phenocryst) slate. It was truncated northward by the Kangxiwa fault and extended southeastward beyond the zone for approximately $60-\mathrm{km}$. Many new metallogenic clues ( 7 mineralization points in the northwest section and 3 mineralization points in the southeast section) have been discovered in the belt through geochemical surveying of stream sediments, remote sensing anomaly verification, and detailed surface tracing, together with an exploration trench-revealing project (Fig. 2).

\section{KEY TECHNOLOGIES AND METHODS}

The WorldView-2 satellite could provide an 8 band, 1.84-m resolution, multispectral image and 0.46-m panchromatic image, with 4 industry standard bands (red, green, blue, near-infrared) and 4 additional bands (blue indigo, yellow, red edge, near-infrared 2). Its diverse spectrum contains abundant spectral information (0.400-1.040 um), while its extremely high spatial resolution can accurately reflect the structure, shape, texture, and other characteristics of objects; thus, the WorldView-2 satellite is a fine data source for geological remote sensing (ZHU, 2003; JIN et al., 2013). The WorldView-2 remote sensing image data used in this paper was from May 2010.
The IKONOS satellite, manufactured by LOCKHEED MARTIN, could collect 1-m resolution full colour and 4-m resolution multispectral images; the full colour and multispectral images could be blended into the 1-m resolution colour images. In this paper, the IKONOS remote sensing image data used was from June 2010.

ASTER is a multispectral imager mounted on the Terra satellite, the received information of which includes the spectral reflectance of the ground in the VNIR (visible and near-infrared) and SWIR (thermal infrared) bands, and thermal radiation of the ground in the TIR range (thermal infrared). Due to the wide wavelength range, several bands, and reasonable cost performance for the data, ASTER is widely used in extracting remote sensing (mineralization) alteration anomaly information (ZHANG et al., 2006).

The high spatial resolution data of WorldView-2 and IKONOS were taken as the main information sources to establish standard remote sensing image maps through image preprocessing, geometric correction, image fusion, image enhancement, and image mosaic. On this basis, image enhancement was processed by band combination transform, principal component transform information decomposition, multiple principal component analysis (PCA), and differential stretching.

\subsection{Production of standard remote sensing images}

According to the principle of band selection, the bigger the variance of band radiation and the smaller the band correlation is, the better. Through calculation of the best index, or optimum index factor for B8 (R) B4 (G) B3 (B) of WorldView-2, and B3 (R) B2 (G) B1 (B) and B4 (R)B2 (G) B1 (B) of IKONOS, image fusion was performed using intensity-hue-saturation (IHS) transform, principal component transform, and PANSHARP. Afterwards, a 1:50000 topographic map and digital elevation model (DEM) data were used for selecting the rational polynomial coefficient parameter correction model to carry out orthorectification and cubic convolution resampling. Finally, the inlay mosaic method was used to create an image mosaic, and the base image for remote sensing interpretation was produced.

\subsection{Key methods of image enhancement processing}

\subsubsection{Recognition of lithologic information by band combination} transformation

The characteristics of different lithologies that correspond to the absorption/reflection bands of WorldView-2 and IKONOS were applied into a series of band algebra operations to enhance the lithological information. For example, a combination of band8, band4/band1, and band5/band3 from the WorldView-2 data facilitated identification of diorite, marble, and schist, or highlight the different lithological differences and improve the accuracy of lithological interpretations (Fig. 3a).

\subsubsection{Recognition of lithological information by information} decomposition technology of principal component transform

The information of 532 and 681 principal component transformation was decomposed to fuse the two results and obtain a new image. It contains multiple bands of information and makes the correlation of different bands smaller, thus, enhancing the contrast between the different lithologies. For example, the different mineral contents of iron oxide, biotite, muscovite, feldspar, and quartz in schist yielded strip-like patterns of different tones, of which the orange-red tone with high iron content was either a magnetite-bearing quartz schist or a magnetite belt (Fig. 3b). 

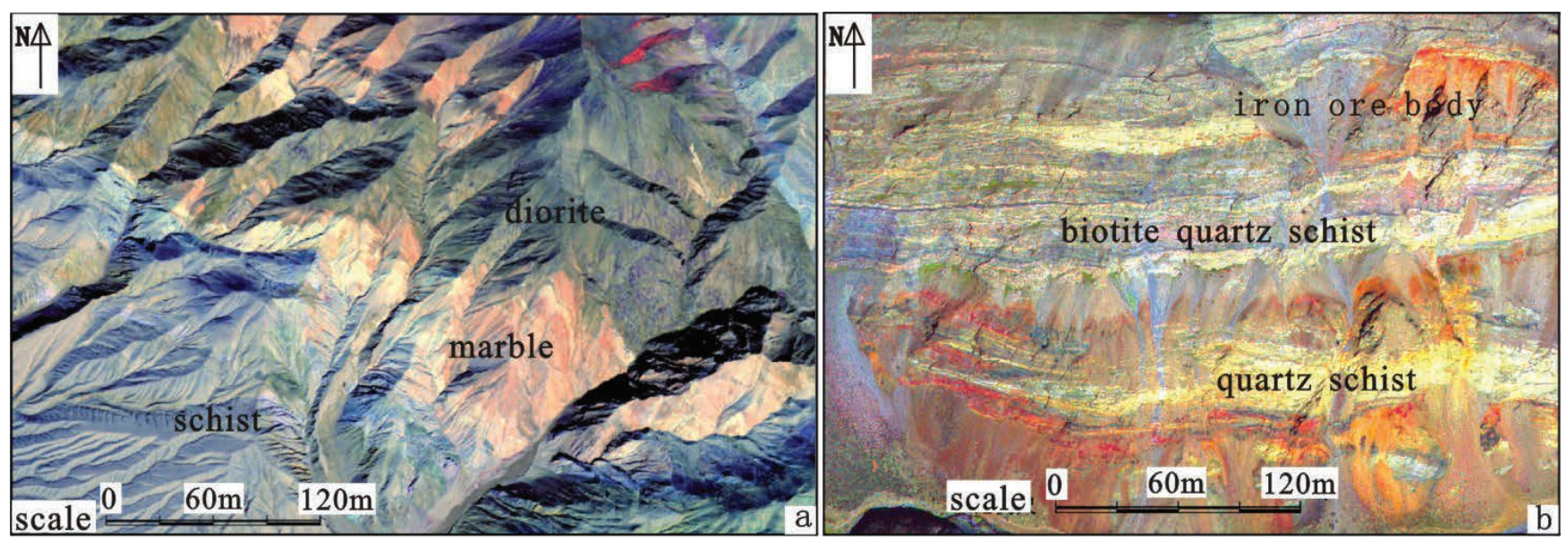

Figure 3. Effects of image enhancement: (a) ratio method to enhance lithology information; (b) principal component transform to enhance lithology information.

\subsubsection{Multiplex principal component analysis}

PCA, band difference, ratio, and the like were used for the extraction of weak geological information in the image, and further, extraction of the most abundant combination of information, secondary processing, or selection of the most favorable result on the thematic information. Specifically, PCA was repeated for the last two objectives and the geological information was enhanced twice.

\subsubsection{Differential stretching}

Initially, the high-resolution remote sensing image of WorldView-2 did not show considerable distinction between the different lithologies, such as whether phyllite and metasandstone were of light blue appearance. Upon application of differential stretching, the distinction became clear, such as the phyllite being light blue and the sandstone being white.

\subsection{Remote sensing mineralization anomaly information extraction}

\subsubsection{Extraction of information of mineralization and alteration based on ASTER}

Several methods can be used to perform extraction of anomaly information in remote sensing (mineralization) alteration, including PCA, ratio analysis, and spectral angle analysis. If the principle considers large-scale ore (often containing high-value anomaly) as a main objective, PCA is the primary choice. Thus, iron staining, hydroxyl, and carbonate anomalies were extracted by principal component transformation, considering the relationship between the absorption spectra of various anomalies and the ASTER band. The main minerals in the area were sedimentary metamorphic magnetite, and the iron stain abnormality was the most direct remote sensing anomaly information with the iron ore. Nonetheless, the relationship between hydroxyl and carbonate anomalies was less related to the iron ore, providing the basis for a focused discussion on iron-stained remote sensing anomaly extraction herein.

$\mathrm{Fe}^{2+}$ generated a strong and broad band at approximately 1.0-1.1 $\mu \mathrm{m}$, whereas $\mathrm{Fe}^{3+}$ exhibited strong absorption at 0.45, $0.55,0.85,0.90$, and $0.94 \mu \mathrm{m}$, specifically indicating a strong absorption band between $0.9-1.0 \mu \mathrm{m}$ and a relatively strong reflection between $0.6-0.8 \mu \mathrm{m}$. According to the relationship between the abnormal absorption spectrum of iron staining and the AS-
Table 1. Abnormal absorption band of iron, hydroxyl and carbonates.

\begin{tabular}{llll}
\hline lon, perssad & absorption spectrum/ $\mu \mathrm{m}$ & ASTER band & typical minerals \\
\hline & $\mathrm{Fe}^{2+}: 1.10 \sim 2.40$ & & limonite, hematite, \\
$\mathrm{Fe}^{2+}, \mathrm{Fe}^{3+}$ & $\mathrm{Fe}^{3+}: 0.45,0.55,0.85$, & Band1, Band3 & $\begin{array}{l}\text { goethite, jarosite and } \\
\text { magnetite }\end{array}$ \\
\hline
\end{tabular}

Table 2. Feature matrix of principle component transform (B1, B2, B3, B4).

\begin{tabular}{lcccc}
\hline Feature vector & Band 1 & Band 2 & Band 3 & Band 4 \\
\hline PC1 & 0.39 & 0.48 & 0.53 & 0.59 \\
PC2 & 0.52 & 0.34 & 0.16 & -0.77 \\
PC3 & 0.68 & -0.14 & -0.67 & 0.26 \\
PC4 & 0.33 & -0.80 & 0.50 & -0.02 \\
\hline
\end{tabular}

TER data band (Table 1), the iron stain information was reflected mainly in B1 to B4 bands, with strong absorption in B1 and B3, and strong reflection in $\mathrm{B} 2$ and $\mathrm{B} 4$.

Iron alteration information (FCA) extraction: Principal component transformation was performed for B1, B2, B3, and B4 bands of the ASTER data, with the mean $+4 \mathrm{~s}$ (standard deviation) as the dynamic range of the principal component output. The iron dye information was absorbed in ASTER data bands 1 and 3 and reflected in bands 2 and 4, thereby, the eigenvectors of the anomalous principal components were characterized by the opposite sign of the contribution coefficients of bands 1 and 3 and bands 2 and 4 . After the principal components of 1, 2, 3, and 4 were transformed to obtain the feature matrix (Table 2), the fourth principal component band 2 was opposite the band 1 and band 3 symbols, but was the same as the band 4 symbol, and therefore, could be used as the main component of the iron-staining anomaly.

\subsubsection{Extraction of information of mineralization and alteration based on WorldView-2}

The centres of the unusual absorption spectra of iron staining were $0.45,0.55,0.85$, and $0.90 \mu \mathrm{m}$, corresponding to B1, B2, B3, $\mathrm{B} 7$, and $\mathrm{B} 8$ of the WorldView-2 data. Accordingly, the reflective characteristic spectra were within $0.60-0.80 \mu \mathrm{m}$, corresponding to B4, B5, and B6 of the WorldView-2 data, of which, B1 and B8 showed strong absorption while $\mathrm{B} 4$ showed strong reflection. As a method of orthogonally transforming several specific bands, PCA could be employed to remove the correlation between bands 


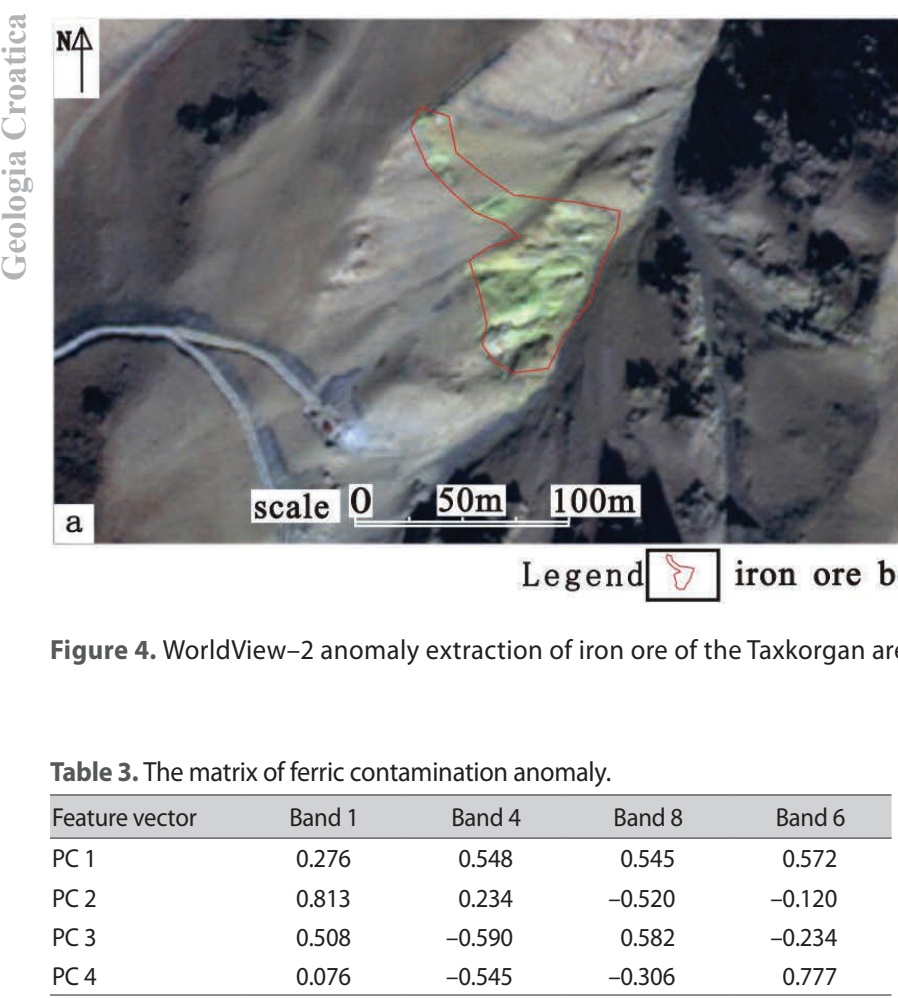

Table 4. The matrix of ferric contamination anomaly.

\begin{tabular}{lcccr}
\hline feature vector & B1 & B3 & B4 & \multicolumn{1}{c}{ B2 } \\
\hline PC1 & 0.383 & 0.549 & 0.505 & 0.544 \\
PC2 & -0.704 & 0.270 & 0.578 & -0.313 \\
PC3 & -0.571 & 0.268 & -0.499 & 0.594 \\
PC4 & 0.178 & 0.744 & -0.403 & -0.503 \\
\hline
\end{tabular}

and reduce the dimension of data, for concentration of as much useful information as possible, into a small number of band images. In PCA, each principal component often represents a certain unique geological significance.

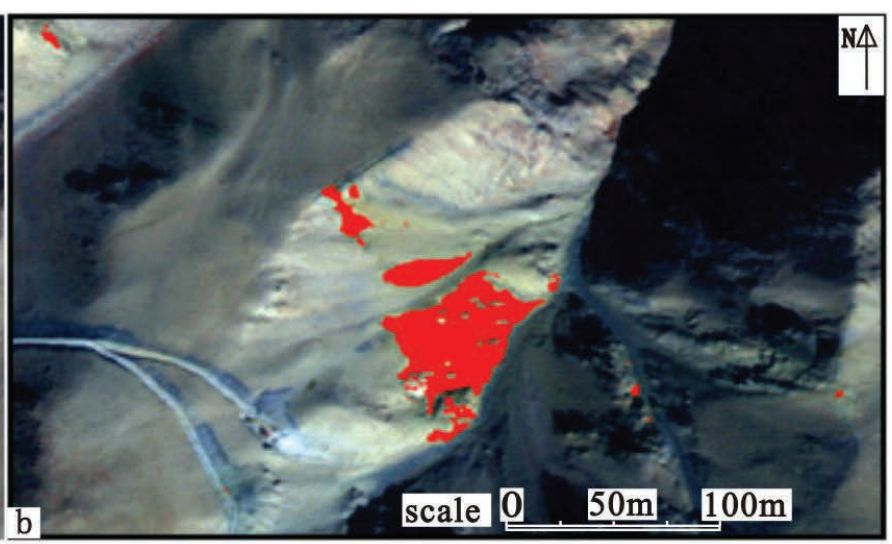

iron alteration anomaly

((a) high-resolution image of the ore body; (b) iron alteration anomaly).

After the principal components B1, B4, B6, and B8 of the Worldview-2 data were transformed to obtain the feature matrix (Table 3), the coefficient of B4 was found opposite to the coefficient of B1 and B8, but was the same as the B6 coefficient, and therefore, could be used as a principal component of the ironstaining anomaly.

In this study, PCA was applied for extraction of the iron ore mineralization (iron staining) remote sensing anomaly information. PC3 was the characteristic principal component of such an anomaly, in which the low-value area became the high-value area of the anomaly. The lower limit of abnormality was determined according to the mean $+3 \delta$ (standard deviation), with the apparent extracted iron staining anomaly and higher degree of coincidence with the known iron ore body (Fig. 4).

\subsubsection{Extraction of information of mineralization and alteration} based on IKONOS

The centres of absorption spectra of iron staining were $0.45,0.55$, 0.85 and $0.90 \mu \mathrm{m}$, corresponding to B1 of the IKONOS data.

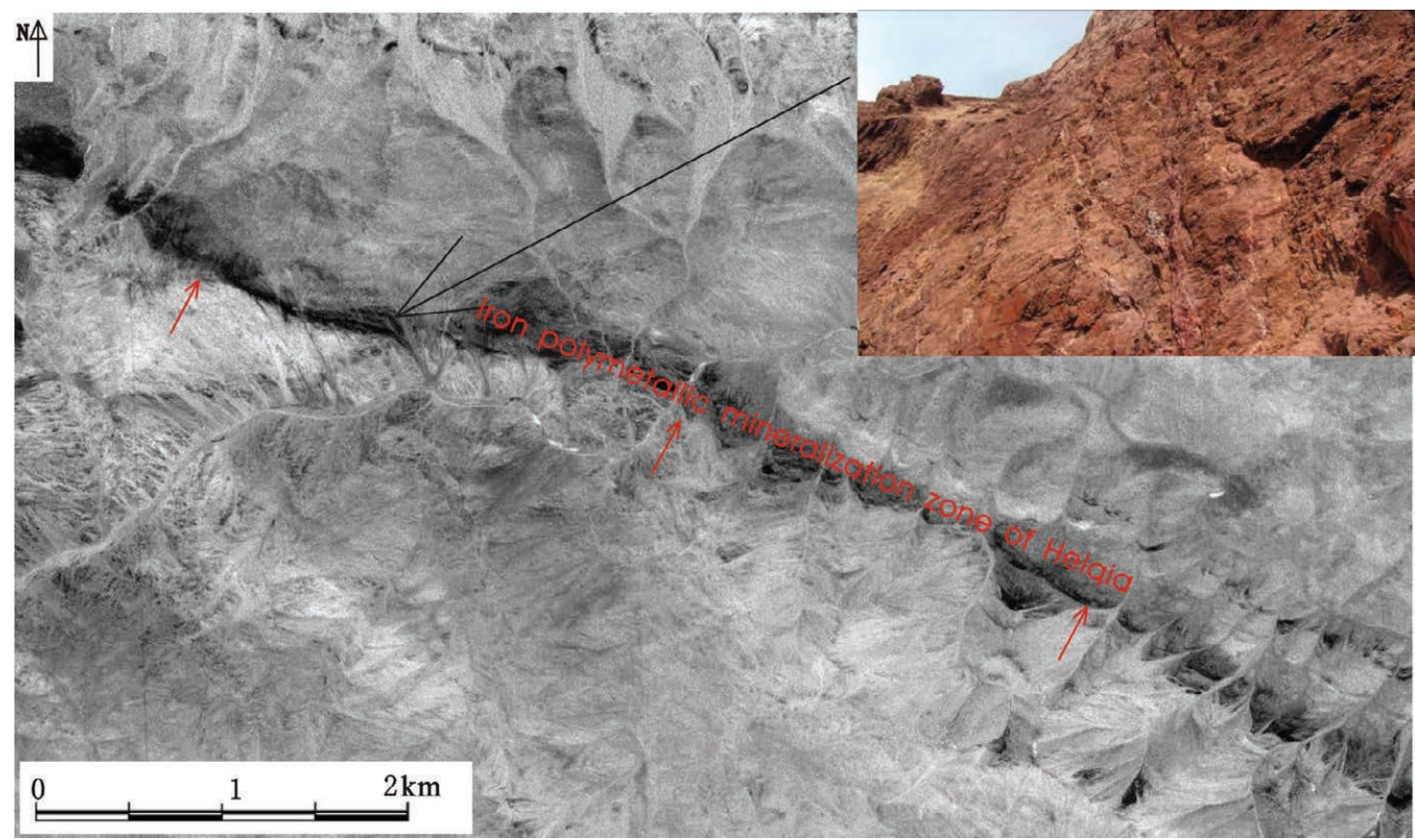

Figure 5. Ferric contamination anomaly of IKONOS remote sensing data in Heiqia (photos of the iron field in the upper-right corner). 
Accordingly, the reflective characteristic spectra were within $0.60-0.80 \mu \mathrm{m}$, corresponding to B3 of the IKONOS data.

After the principal components B1, B3, B4, and B2 were transformed to obtain the feature matrix (Table 4), the coefficient of B3 was found opposite those of B1 and B4, but was the same as the B2 coefficient, and, therefore, could be used as the principal component of the iron-staining anomaly.

The lower limit of abnormality was determined according to the mean $+3 \delta$ (standard deviation), with the banded extracted iron staining anomaly (Fig. 5).

\section{REMOTE SENSING GEOLOGICAL CHARACTERISTICS}

\subsection{Remote sensing geological characteristics of iron ore in the Taxkorgan area}

The WorldView-2 data were combined with the B8 (R) B4 (G) B3 (B) band, whereas the DEM data were employed for orthorectification. A full colour band fusion process was used to achieve a $0.46-\mathrm{m}$ fusion image resolution, later enhanced and transformed to highlight the lithology, structure, and iron ore (body) information.

\subsubsection{Stratigraphic lithology}

Within the study area, magnetite was localized in the iron-bearing section of the Brongol Group $\left(\mathrm{Pt}_{1} B\right)$. The main lithology included (iron-stained) biotite quartz schist, followed by gneiss with hornblende and biotite, magnetite quartz schist, two mica quartz schist, sericite quartz schist with magnetite, a small number of gneiss with plagioclase and hornblende, chlorite schist, and marble. On the combined image of B8 (R) B4 (G) B3 (B) band from the WorldView-2 data, biotite quartz schist was dark gray-black with a striped pattern and medium weathering resistance, and mostly formed a gentle slope microtopography that was most closely related to the magnetite space, as the wall rock of the ore body (Fig. 6a). Biotite plagioclase gneiss (including magnetites?) was dark gray to dark gray in tone with a striped pattern and strong weathering resistance, and mostly formed a striped steep ridge microtopography that was closely related to the magnetite space as the important ore hosting wall rock. Moreover, magnetite quartz schist was gray-gray in tone with a narrow strip-like pattern and strong weathering resistance, and mostly formed a normal topography that was closely related to the magnetite space, often located in the magnetite mineralization zone. The dimica quartz schist was bright gray to dark gray or variegated tones with a banded pattern and medium weathering resistance, and mostly formed a gentle slope microtopography. Sericite quartz schist was bright gray-white tones with a fine striped pattern and medium weathering resistance, and mostly formed a similar gentle slope microtopography. Plagioclase amphibolite schist (gneiss) was dark gray-dark gray-greengray-black tones with a dark tone, banded or massive schistosomiasis, weak or non-schistosomiasis. Chlorite schist was dark gray-green to dark gray in tone, with fine strip-like patterns and weak weathering resistance, and mostly formed gentle slopes or negative topographic micro-landforms. Marble was bright grayyellow to gray-white in colour, with banded and irregular blocklike patterns and strong weathering resistance, and was generally dominated by a normal topography (Fig. 6b).

\subsubsection{Structure}

The study area was located in the Taxkorgan landmass, with the Taasi-Sekblak and Kangxiwa-Wacha junction zones as the northern and southern boundaries, respectively. Faults and folds were well developed in the area, at a NW dominant structural orientation, consistent with the strike of the north-south boundary faults. Most of the faults were compressive (torsional) structures. The image showed apparent linear structural features, which could form linear tone shadow abnormal zones and a linear negative topography. Moreover, hues and textures on both sides of the fracture were significantly different, often forming different image volume boundaries (Fig. 7a). Some magnetite bodies in the area were reformed by secondary fracture structures, as manifested in two situations. First, under the influence of hydrothermal fluid $\left(>300{ }^{\circ} \mathrm{C}\right)$, the thickness of the ore body increased and its grade became rich. Second, under no hydrothermal coordination or low hydrothermal temperature $(<300$ ${ }^{\circ} \mathrm{C}$ ), the ore fabric changed, mostly in the form of fragmentation and breccia, and the ore body continuity was destroyed to varying degrees. The fold structure showed the same set of banded image bodies on the image map, or an image marker layer with mirror symmetry and repeated distribution in space, continuous along the upwardly-inclined or back-tilted end. Such distinct features were easily identifiable (Fig. 7b). As an integral part of the stratum, the iron ore body was deformed synchronously with
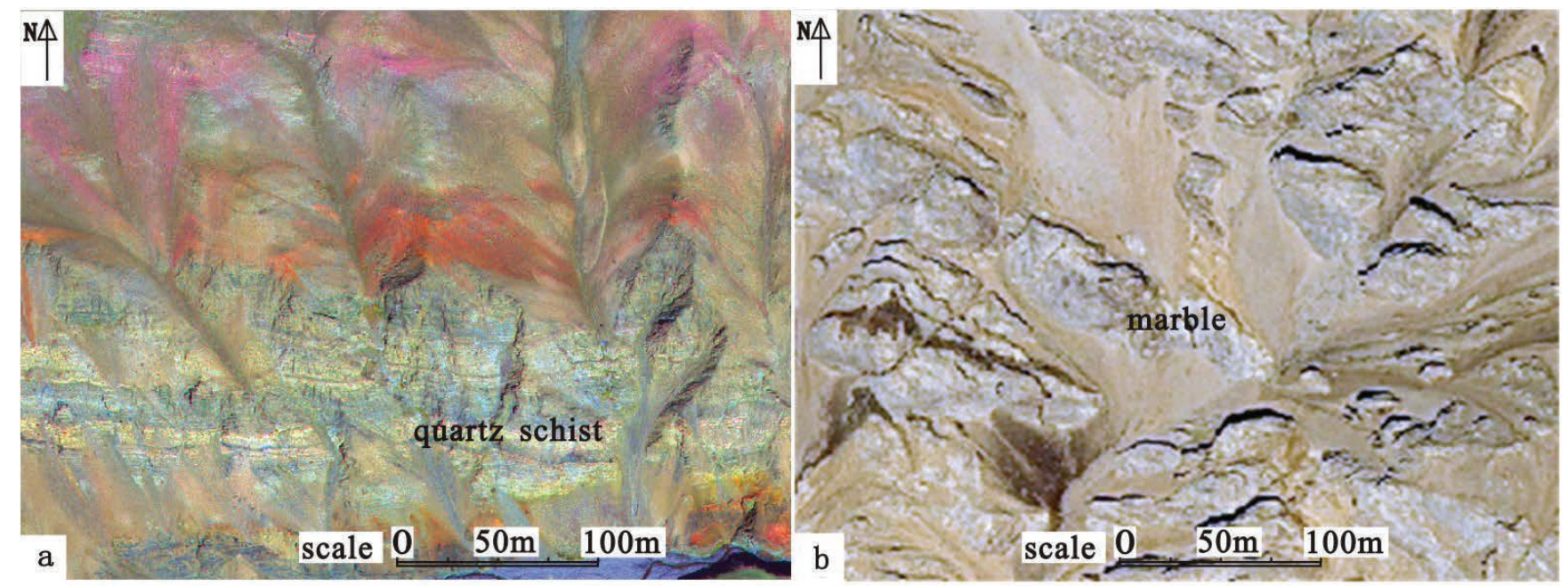

Figure 6. Image features of (a) quartz schist and (b) marble in Taxkorgan. 


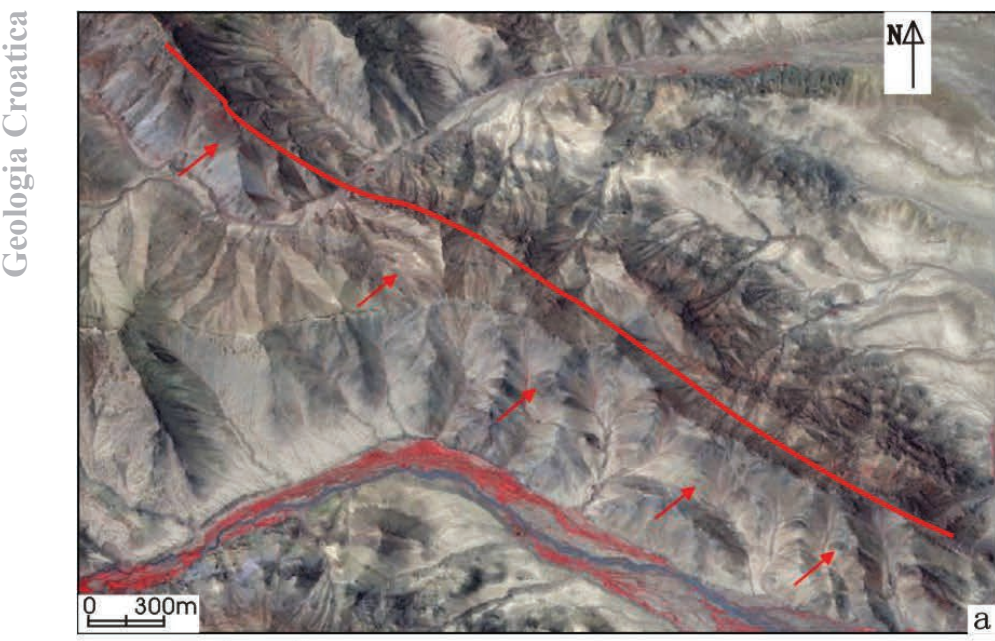

Legend $\backslash$ Tectonic belt of Taaxi-Sekebulake

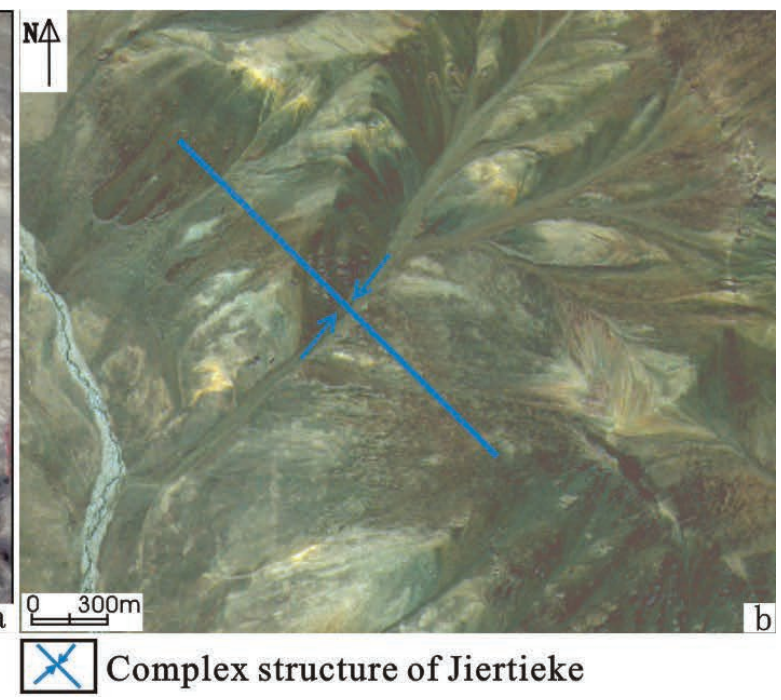

Figure 7. Remote sensing image features of the tectonic belt in Taxkorgan ((a) tectonic belt of Taaxi-Sekebulake and (b) complex structure of Jiertieke).
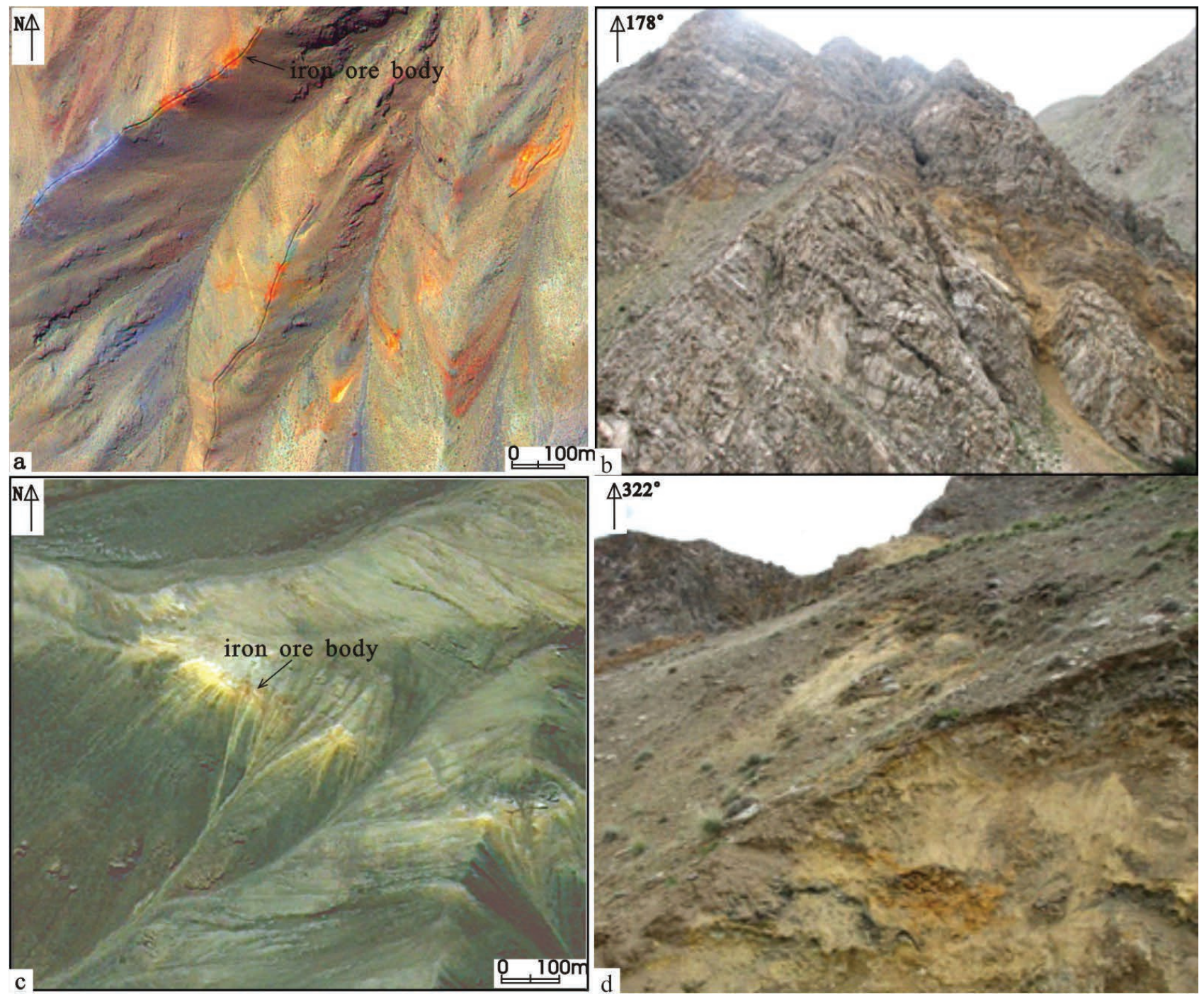

Figure 8. Remote sensing image features of iron ore bodies in Taxkorgan ((a) Quickbird; (b) Laobing iron mine; (c) WorldView-2 and; (d) Zoukebengou iron mine).

the ore-bearing surrounding rock, under the action of longitudinal bending and folding. Additionally, under the action of flattening, the thickness of the wing ore body was reduced while that of the turning end body was increased.

\subsubsection{Ore body, mineralized zone}

The field observation results indicated that most magnetite ores are ferrous black and gray-black and have irregular (thick, massive, layered, and lenticular) bodies. Specifically, the occurrence 
of the ore bodies was similar to those of the roof and floor wall rocks. The ore hosting rocks were mainly biotite quartz schist, followed by biotite plagioclase gneiss, magnetite quartz schist, and quartz schist. In the Laobing area, the iron ore bodies were patchy (dotted), beaded, and distributed intermittently along the foliation direction (Fig. 8b). Here, magnetite was a bright orangeyellow-hue on the B8(R)B4(G)B3(B) band, combined with a high-score image of Quickbird (Fig. 8a). The Kebengou iron ore belt with good continuity was distributed in regular strips (Fig. 8d). Due to differences in surface scale, occurrence, and outcropping degree of the iron ore bodies, their shape and shadow structures were also different.

\subsubsection{Iron ore belt distribution along the area of ore concentration}

Based on the extracted remote sensing (mineralization) alteration information and remote sensing interpretation of the main ore controlling elements, the distribution of mineralization zones in the iron ore belt was preliminarily obtained through a comprehensive remote sensing interpretation of their lithology, structure, intrusive rocks, ore bodies, and mineralization zones in the area of ore concentration. Specifically, the iron ore (mineralization) zones in the study area were distributed as follows (Fig. 9): (1) The Zankan iron ore (mineralization) belt extends $5 \mathrm{~km} \mathrm{NW}$ to SE, from the Mokart Snow Mountain (Pl. 1a, b). The Laohe-YeliteTaasi iron ore (mineralization) belt extends over a 21-km-long and 1-2-km-wide NW-SE distribution. There were 2 to 4 mineral veins in this belt, occurring as stratified or stratoid in form (Pl. 1c, d; Fig.8b). Similarly, the Zoukeben-Taaxi iron ore deposit (mineralization) belt lies along a NW-SE distribution that extends to 18 $\mathrm{km}$ and that occurs as discontinuous stratified, stratoid, or lenticular morphologies (Fig. 8d). Moreover, the Yukuli Kukat iron ore (mineralization) belt in the northern Maryang Ocean extended approximately East-West, over a $2 \mathrm{~km}$ distance.

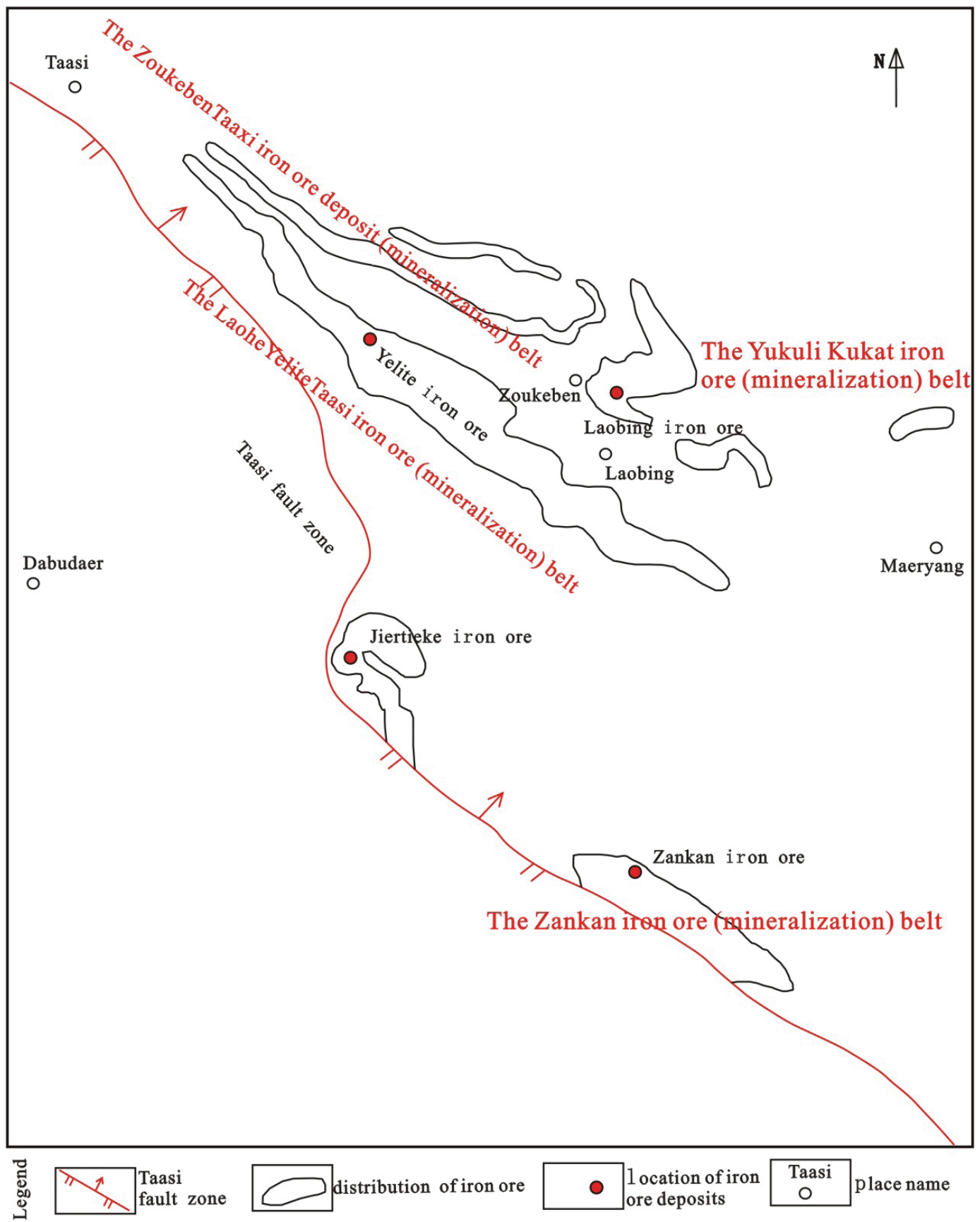

Figure 9. Sketch map of the iron ore, or mineralized zone in the concentration area. 

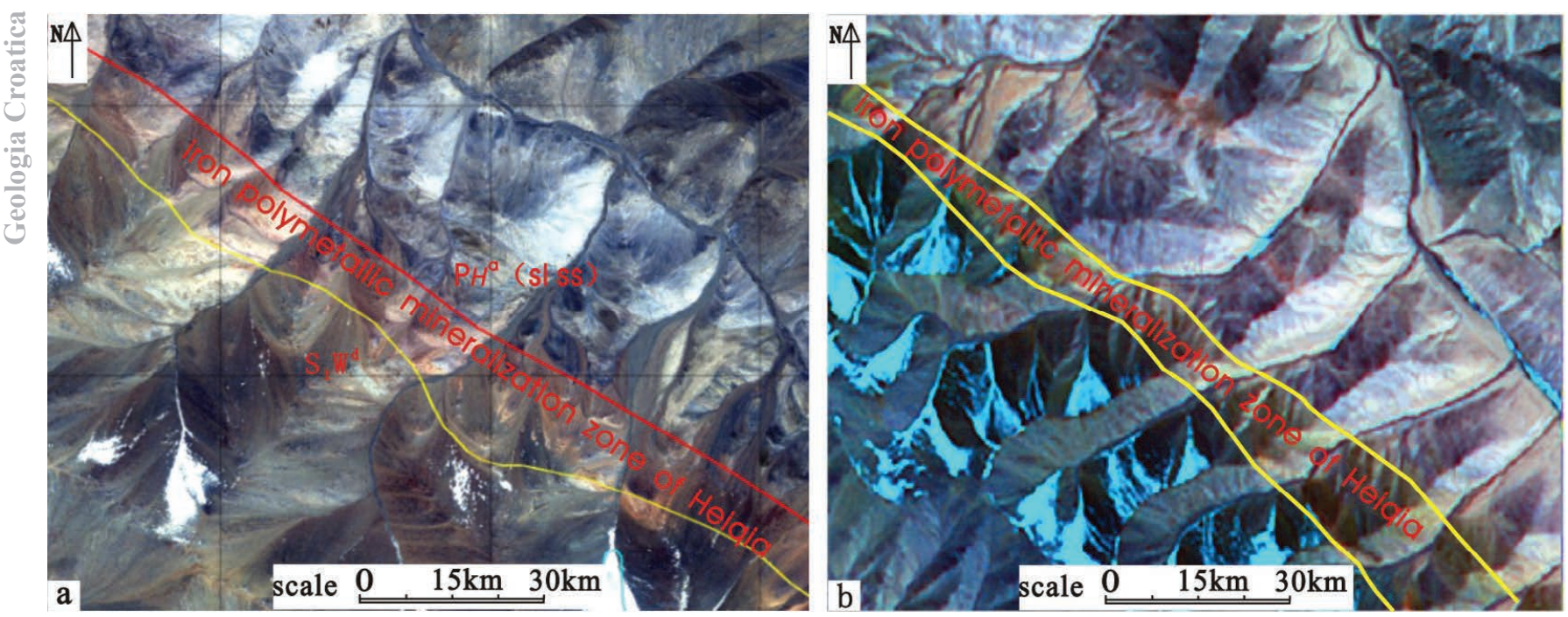

Figure 10. Interpretation key of the Heiqia iron polymetallic mineralization zone in (a) IKONOS and (b) ETM remote sensing data.

\subsection{Remote sensing characteristics of the heiqia iron polymetallic mineralization zone}

\subsubsection{Remote sensing image interpretation markers}

The iron polymetallic mineralization zone of Heiqia in the highresolution remote sensing images of IKONOS (band combination B3 (R) B2 (G) B1 (B)) showed a light brown banded pattern, which was slightly different from the image characteristics of the two sides of the rock layer (Fig. 10a). In the false-colour synthetic image of the enhanced thematic mapper (ETM; band combination B7(R) B4 (G) B3 (B)), the mineralized zone showed a yellow-green tone and regular strip pattern. On both sides of the rock strata, a blue stripe pattern was apparent; although the colour difference between these rocks was apparent and easily distinguished, the boundary was barely discernible (Fig. 10b).

The effect of remote sensing interpretation was enhanced by decorrelating the B3(R) B2 (G) B1 (B) band combination of the IKONOS images. The iron polymetallic mineralization belt of Heiqia was brown in varying depths and regular strip-like pattern in the enhanced image, which was apparently different from the image characteristics of the two lateral strata outside the belt. Nonetheless, the boundary was clear and easily identifiable. Iron ore bodies were located mostly in the middle and lower part of the mineralization zone, with dark reddish-brown tone, narrow strip, lenticular, beaded, and intermittent extension, whereas the boundary with the mineralization zone was clear. Through detailed interpretation, the mineralized bodies were distributed mainly in the northwest part of the mineralized zone, although other areas were difficult to interpret due to the small-scale single mineralized bodies or the serious surface coverage. The tones of floor wall rocks were mainly dark gray-bluedark brown-black with banded shape, whereas the tones of roof wall rocks were light gray-white-light yellowish-brown with banded extension (Fig. 11a). Information decomposition based on the PCA was the common method of enhancing the weak information of geological lithology. Using the IKONOS data in $\mathrm{B} 1, \mathrm{~B} 3, \mathrm{~B} 4$, and $\mathrm{B} 2$ bands for the PCA, band 4 was combined with the original bands 1 and 3 to obtain a new image. The iron polymetallic mineralization belt of Heiqia was a pink tone and banded shadow, obviously different from the image characteristics of the surrounding rock (Fig. 11b).

\subsubsection{Geological characteristics of the Heiqia iron polymetallic mineralization zone}

\section{Geological characteristics of the ore (mineralization) body} in the study area

The ore bodies are of irregular stratoid, lenticular, or podiform appearance, with a few veins having bedding or through the
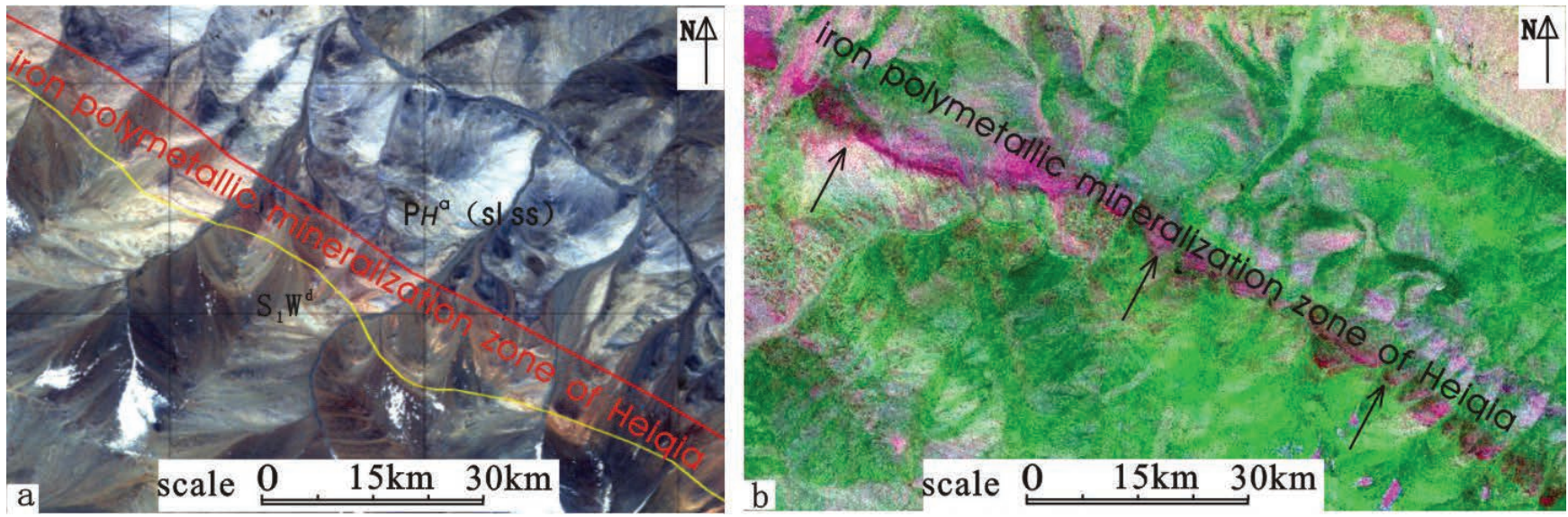

Figure 11. Interpretation key of Heiqia iron polymetallic mineralization zone after enhancement processing of IKONOS remote sensing data ((a) decorrelation analysis and (b) PCA). 
strata, had a sudden change of relationship with the surrounding rocks. It has an inclination of $40^{\circ}-50^{\circ}$ and an angle of $68^{\circ}-81^{\circ}$, consistent with the occurrence of the surrounding rocks. The length of a single ore body was typically tens to hundreds of metres, and its surface outcropping thickness was within tens of centimetres to several metres (Table 5). The boundary between the ore body and the upper and lower footwall was distinctive. The surrounding rock was mainly iron (iron-containing) dolomite, followed by dolomitic limestone, silicified dolomite marble (mostly located in the ore body), and a small amount of other metamorphic clastic rocks (metamorphic sandstone and sandy slate). The wall rocks of the ore body roof were dolomite, iron dolomite, silicified dolomite, marble dolomite, (strip) marble, and a small amount of limestone. The wall rocks of the ore body floor were sandstone, metasandstone, sandy slate, and carbonate rock.

\section{Ore characteristics}

The surface iron ore minerals were mainly limonite, followed by haematite and a small amount of siderite. Galena, blue copper ore, malachite (P1.2d), and occasional? sphalerite, antimony lead ore, white lead ore, and black lead ore, were found in the lead (copper, zinc) associated with the iron ore. Gangue minerals included quartz, muscovite, iron dolomite, and barite, and occasionally graphite, tourmaline, apatite, among others. The iron ore structure was composed mainly of two types: fine grain and the medium grain coarse-grained (variable crystal). Furthermore, the main iron ore structure was of four types: (a) a compact block (P1.2a) and (hidden) lamellar structure formed during the syndepositional period; (b) banded and wrinkled structures formed during the post-metamorphic stage; (c) veins, cavities, clusters, and breccia structures formed during hydrothermal superimposition in the late tectonic stage (Pl.2b); and (d) honeycomb, earth like, colloidal, and tuberculous structures formed after weathering and leaching of the earth's surface. Galena, which forms in the cracked carbonate rocks of the roof of an iron ore body, was mainly of semi-ebony and fine-grained structure (P1.2c). Moreover, it was filled with irregular structural fractures (P1.2e). Likewise, fractured carbonate was filled with structural fractures (Pl.2f), showing disseminated and membranous structures. The $\mathrm{Pb}(\mathrm{Zn})$ ore was closely related to the iron (iron-bearing) dolomite, whereas $\mathrm{Cu}$ mineralization was related closely to dolomitic marble.

Table 5. Basic characteristics of main ore (chemical) points of the Heiqia polymetallic mineralization zone.

\begin{tabular}{|c|c|c|c|c|c|c|}
\hline Position & $\begin{array}{l}\text { Newly discovered mineralized } \\
\text { point }\end{array}$ & $\begin{array}{l}\text { Number of } \\
\text { ore bodies }\end{array}$ & Ore body shape & $\begin{array}{l}\text { Surface scale } \\
\text { long } \times \text { width } / \mathrm{m}\end{array}$ & $\begin{array}{l}\text { Metallogenic element } \\
\text { grade } / \%\end{array}$ & $\begin{array}{l}\text { Main ore } \\
\text { mineral }\end{array}$ \\
\hline \multirow{7}{*}{$\begin{array}{l}\text { Northwest } \\
\text { paragraph }\end{array}$} & No. 1 lead (zinc) iron ore point & 1 & stratiform & $175 \times(4-8)$ & $\begin{array}{l}\mathrm{Fe}(51.03) \\
\mathrm{Pb}(\mathrm{Zn})\end{array}$ & $\begin{array}{l}\text { hematite, limonite, } \\
\text { galena and pyrite }\end{array}$ \\
\hline & No. 2 iron ore point & 1 & stratiform & $170 \times(2-3)$ & $\mathrm{Fe}(43.35)$ & hematite, limonite \\
\hline & $\begin{array}{l}\text { No. } 3 \text { containing lead-zinc iron } \\
\text { ore point }\end{array}$ & 1 & lentoid & $40 \times(0.5-8)$ & $\mathrm{Fe}(33.10)$ & $\begin{array}{l}\text { hematite, limonite, } \\
\text { galena }\end{array}$ \\
\hline & No. 4 lead (zinc) iron ore & 1 & $\begin{array}{l}\text { stringer of penetrating } \\
\text { layer }\end{array}$ & $30 \times(0.1-0.3)$ & $\begin{array}{l}\mathrm{Fe}(32.65) \\
\mathrm{Pb}(\mathrm{Zn})\end{array}$ & $\begin{array}{l}\text { hematite, limonite, } \\
\text { galena }\end{array}$ \\
\hline & No. 5 lead-zinc ore & 1 & stringer of bedding rock & $30 \times 0.4$ & $\mathrm{~Pb}+\mathrm{Zn}(2.37)$ & $\begin{array}{l}\text { hematite, limonite, } \\
\text { galena, sphalerite }\end{array}$ \\
\hline & $\begin{array}{l}\text { No. } 6 \text { containing lead-zinc iron } \\
\text { ore point }\end{array}$ & 1 & stringer of bedding rock & $150 \times 0.74$ & $\mathrm{Fe}(31.10), \mathrm{Pb}+\mathrm{Zn}(2.35)$ & $\begin{array}{l}\text { hematite, limonite, } \\
\text { galena, sphalerite }\end{array}$ \\
\hline & No. 7 copper ore & 1 & stringer of bedding rock & $1700 \times(0.5-0.7)$ & $\mathrm{Cu}(0.86)$ & malachite \\
\hline \multirow{3}{*}{$\begin{array}{l}\text { Southeast } \\
\text { paragraph }\end{array}$} & $\begin{array}{l}\text { No. } 8 \text { iron lead mineralization } \\
\text { point }\end{array}$ & 3 & stringer of bedding rock & $? \times(2.0-20)$ & $\mathrm{Fe}(37.46), \mathrm{Pb}(0.24-1.13)$ & \\
\hline & $\begin{array}{l}\text { No. } 9 \text { iron, copper and lead } \\
\text { mineralization point }\end{array}$ & 5 & stringer of bedding rock & $200 \times(1-5)-900 \times(1-5)$ & $\mathrm{Cu}(0.27-0.49), \mathrm{Pb}(0.69)$ & $\begin{array}{l}\text { malachite, hematite, } \\
\text { limonite, pyrite, } \\
\text { chalcopyrite, galena }\end{array}$ \\
\hline & No. 10 iron ore point & 1 & stringer of bedding rock & $300 \times 6$ & $\mathrm{Fe}(29.90)$ & hematite, limonite \\
\hline
\end{tabular}

Table 6. Remote sensing model of sedimentary metamorphic type magnetite deposits in the Taxkorgan study area.

\begin{tabular}{|c|c|c|c|c|c|c|}
\hline Position & $\begin{array}{l}\text { Newly discovered mineralized } \\
\text { point }\end{array}$ & $\begin{array}{l}\text { Number of } \\
\text { ore bodies }\end{array}$ & Ore body shape & $\begin{array}{l}\text { Surface scale } \\
\text { long } \times \text { width } / \mathrm{m}\end{array}$ & $\begin{array}{l}\text { Metallogenic element } \\
\text { grade } / \%\end{array}$ & $\begin{array}{l}\text { Main ore } \\
\text { mineral }\end{array}$ \\
\hline \multirow{7}{*}{$\begin{array}{l}\text { Northwest } \\
\text { paragraph }\end{array}$} & No. 1 lead (zinc) iron ore point & 1 & stratiform & $175 \times(4-8)$ & $\begin{array}{l}\mathrm{Fe}(51.03) \\
\mathrm{Pb}(\mathrm{Zn})\end{array}$ & $\begin{array}{l}\text { hematite, limonite, } \\
\text { galena and pyrite }\end{array}$ \\
\hline & No. 2 iron ore point & 1 & stratiform & $170 \times(2-3)$ & $\mathrm{Fe}(43.35)$ & hematite, limonite \\
\hline & $\begin{array}{l}\text { No. } 3 \text { containing lead-zinc iron } \\
\text { ore point }\end{array}$ & 1 & lentoid & $40 \times(0.5-8)$ & $\mathrm{Fe}(33.10)$ & $\begin{array}{l}\text { hematite, limonite, } \\
\text { galena }\end{array}$ \\
\hline & No. 4 lead (zinc) iron ore & 1 & $\begin{array}{l}\text { stringer of penetrating } \\
\text { layer }\end{array}$ & $30 \times(0.1-0.3)$ & $\begin{array}{l}\mathrm{Fe}(32.65) \\
\mathrm{Pb}(\mathrm{Zn})\end{array}$ & $\begin{array}{l}\text { hematite, limonite, } \\
\text { galena }\end{array}$ \\
\hline & No. 5 lead-zinc ore & 1 & stringer of bedding rock & $30 \times 0.4$ & $\mathrm{~Pb}+\mathrm{Zn}(2.37)$ & $\begin{array}{l}\text { hematite, limonite, } \\
\text { galena, sphalerite }\end{array}$ \\
\hline & $\begin{array}{l}\text { No. } 6 \text { containing lead-zinc iron } \\
\text { ore point }\end{array}$ & 1 & stringer of bedding rock & $150 \times 0.74$ & $\mathrm{Fe}(31.10), \mathrm{Pb}+\mathrm{Zn}(2.35)$ & $\begin{array}{l}\text { hematite, limonite, } \\
\text { galena, sphalerite }\end{array}$ \\
\hline & No. 7 copper ore & 1 & stringer of bedding rock & $1700 \times(0.5-0.7)$ & $\mathrm{Cu}(0.86)$ & malachite \\
\hline \multirow{3}{*}{$\begin{array}{l}\text { Southeast } \\
\text { paragraph }\end{array}$} & $\begin{array}{l}\text { No. } 8 \text { iron lead mineralization } \\
\text { point }\end{array}$ & 3 & stringer of bedding rock & $? \times(2.0-20)$ & $\mathrm{Fe}(37.46), \mathrm{Pb}(0.24-1.13)$ & \\
\hline & $\begin{array}{l}\text { No. } 9 \text { iron, copper and lead } \\
\text { mineralization point }\end{array}$ & 5 & stringer of bedding rock & $200 \times(1-5)-900 \times(1-5)$ & $\begin{array}{l}\mathrm{Cu}(0.27-0.49) \\
\mathrm{Pb}(0.69)\end{array}$ & $\begin{array}{l}\text { malachite, hematite, } \\
\text { limonite, pyrite, } \\
\text { chalcopyrite, galena }\end{array}$ \\
\hline & No. 10 iron ore point & 1 & stringer of bedding rock & $300 \times 6$ & Fe (29.90) & hematite, limonite \\
\hline
\end{tabular}




\section{Ore grade}

The results of the surface sampling and laboratory test showed a total iron? (TFe) grade within the range of $29.90 \%$ to $51.03 \%$ and an average grade of $36.94 \%$, whereas $\mathrm{Pb}+\mathrm{Zn}$ in the lead-zinc ore body had a grade within $0.24 \%$ to $2.37 \%$, and that of $\mathrm{Cu}$ in the copper ore body was within $0.27 \%$ to $0.86 \%$.

\section{Metallogenic regularity and zoning characteristics of the metallogenic elements}

The results of the systematic field investigation showed that the NW-SE development of the iron ore bodies deteriorated gradually, and the surface thickness of the mineralized bodies decreased gradually, together with the strike extension length of the single ore bodies. Spatially, the iron polymetallic mineralization zone was closely related to the carbonate rocks on the roof of the ore body. Carbonate rocks were developed in all occurrences of the iron ore body, although its thickness often had insignificant or negative correlation with the thickness of the carbonate rocks. Along the strike of the mineralization zone, metallogenic elements NW-SE generally showed the zoning rule of $\mathrm{Pb}-\mathrm{Zn}$ - $\mathrm{Cu}$ elements.
As the iron ore body's thickness reduced, the $\mathrm{Pb}$ content decreased gradually, while that of $\mathrm{Zn}$ gradually increased. Moreover, as the $\mathrm{Cu}$ content increased in the pinch-out area of the iron ore bodies, the element's independent ore bodies appeared.

\section{REMOTE SENSING INTEGRATED PROSPECTING MODEL}

Based on the analysis of the metallogenic geological characteristics of the Taxkorgan and Heiqia iron deposits, interpretation of high-resolution remote sensing of ore controlling elements, and extraction of anomalous information of remote sensing mineralization and alteration, a comprehensive remote sensing prospecting model based on high-resolution remote sensing images was established and supported by field validation and correction (Table 6, Table 7).

\section{CONCLUSIONS}

(1) WorldView-2 and IKONOS remote sensing images were used as major data sources for the creation of a standard image map and for the adoption of image enhancement methods to ex-

Table 7. Remote sensing geology prospecting model of the Heiqia iron polymetallic mineralization zone in West Kunlun region.

\begin{tabular}{|c|c|c|}
\hline \multicolumn{2}{|c|}{ Ore controlling factors } & \multirow{2}{*}{$\begin{array}{l}\text { Prospecting model } \\
\text { Rift tectonic environment of the Taxkorgan block }\end{array}$} \\
\hline \multirow{7}{*}{$\begin{array}{l}\text { Geological } \\
\text { conditions }\end{array}$} & Geotectonic location & \\
\hline & Ore hosting strata & Formation of Blungule Group in Paleoproterozoic (ferriferous section) \\
\hline & Metallogenic environment & $\begin{array}{l}\text { Early shallow, semi-deep sea sedimentary environment, exhalative sedimentary metallogenic in the intermittent } \\
\text { period of submarine volcanic activity, after mineralization by regional metamorphism and deformation transforma- } \\
\text { tion }\end{array}$ \\
\hline & $\begin{array}{l}\text { Surrounding rocks of mineralized } \\
\text { body }\end{array}$ & $\begin{array}{l}\text { Main lithology of (iron-dyed) biotite quartz schist, followed by (including magnet) black cloud slant gneiss, magnetite } \\
\text { quartz schist, two mica quartz schist, sericite quartz schist with magnetite, a small number of oblique long-angle } \\
\text { flash schist (gneiss), chlorite schist, and marble }\end{array}$ \\
\hline & Ore controlling structure & $\begin{array}{l}\text { Well developed faults and folds in the area; NW dominant structural orientation, which is consistent with the strike of } \\
\text { the north-south boundary faults }\end{array}$ \\
\hline & Wall rocks near the ore & $\begin{array}{l}\text { Altered minerals of wall rocks that are mainly marbleization, actinolitization, chloritization, sericitization, ferritization, } \\
\text { among others }\end{array}$ \\
\hline & $\begin{array}{l}\text { Criteria of field geological } \\
\text { prospecting }\end{array}$ & $\begin{array}{l}\text { Magnetite body of a strong weathering resistance and whose outcrop is the most direct prospecting indicator; ore } \\
\text { body that is black and gray from a distance and brown sauce from a near view; pyrite components in the ores that are } \\
\text { easily weathered to form jarosite and limonite }\end{array}$ \\
\hline \multirow{2}{*}{$\begin{array}{l}\text { Remote sensing } \\
\text { characteristics }\end{array}$} & High-score image features & $\begin{array}{l}\text { Ore bodies in the WorldView-2 image have beige-yellowish-green tones, stretching intermittently in strips, pods, } \\
\text { and beads }\end{array}$ \\
\hline & $\begin{array}{l}\text { Remote sensing anomaly } \\
\text { information }\end{array}$ & Iron alteration anomaly \\
\hline \multirow{7}{*}{$\begin{array}{l}\text { Geological } \\
\text { conditions }\end{array}$} & Geotectonic location & $\begin{array}{l}\text { Northern margin of the Qiangtang-Tanggula Block, south of Kangxiwa-Muzitage-Animaqing Late Paleozoic junction } \\
\text { belt }\end{array}$ \\
\hline & Ore hosting strata & D formation of the Wenquangou group in Early Silurian $\left(S_{1} W^{d}\right)$ \\
\hline & Metallogenic environment & $\begin{array}{l}\text { Located in fine clasolite and carbonate formations of littoral-shallow-shelf facies at the top of D Formation of the } \\
\text { Wenquangou Group in Early Silurian with stable horizons and obvious stratabound characteristics }\end{array}$ \\
\hline & $\begin{array}{l}\text { Surrounding rocks of mineralized } \\
\text { body }\end{array}$ & $\begin{array}{l}\text { Wall rocks of the ore body roof such as dolomite, iron dolomite, silicified dolomite, marble dolomite, (strip) marble, } \\
\text { and a small amount of limestone; wall rocks of the ore body floor such as sandstone, metasandstone, sandy slate and } \\
\text { carbonate rock }\end{array}$ \\
\hline & Ore controlling structure & Secondary faults, structural fissures, and interlayer fracture zones of carbonate rocks associated with the Karatag fault \\
\hline & Wall rocks near the ore & $\begin{array}{l}\text { Surrounding rock alteration that is generally weak; sericitization, chloritization, carbonation, and silicification that are } \\
\text { common only in the surrounding rocks with strong tectonic reformation in the latter stage; apparent malachitization, } \\
\text { blue copper mineralization, or lead-zinc mineralization in the mineralization zone }\end{array}$ \\
\hline & $\begin{array}{l}\text { Criteria of field geological } \\
\text { prospecting }\end{array}$ & $\begin{array}{l}\text { An ore body closely related to the iron dolomite in space; iron dolomite that is dark-yellow brown after oxidation on } \\
\text { the surface and is easily identifiable, which is a good prospecting indicator; exposure of the primary siderite on the } \\
\text { surface, followed by its transformation into iron oxides, such as hematite and limonite under oxidation to form an } \\
\text { "iron cap," which can directly guide the search for the primary siderite }\end{array}$ \\
\hline \multirow[t]{2}{*}{$\begin{array}{l}\text { Remote sensing } \\
\text { characteristics }\end{array}$} & High-score image features & $\begin{array}{l}\text { Mineralized zones turning brown in different depths and regular strip-like pattern, after decorrelation analysis and } \\
\text { enhancement of the B3(R)B2(G)B1(B) band combination of IKONOS; clear and easily identifiable boundary; iron ore } \\
\text { bodies of dark reddish brown tone, narrow strip, lenticular, beaded, and intermittent extension, and whose boundary } \\
\text { with the mineralization zone is clear; carbonate rocks of light gray-white-yellowish-brown tones with striped } \\
\text { patterns }\end{array}$ \\
\hline & $\begin{array}{l}\text { Remote sensing anomaly } \\
\text { information }\end{array}$ & Iron alteration anomaly \\
\hline
\end{tabular}

information

Geophysical and geochemical anomaly information

Geophysical information showing magnetic anomalies and geochemical information showing comprehensive anomalies of elements, such as $\mathrm{Pb}, \mathrm{Zn}, \mathrm{Cu}$ and $\mathrm{Au}$ 
tract the information of ore-controlling factors and mineralization and to provide an interpretation of remote sensing for mineral resources. Furthermore, ASTER, WorldView-2, and IKONOS data were utilized to carry out alteration anomaly information extraction. Given appropriate amounts of field sampling and a verification test, large iron ore belts were discovered in the study areas of Taxkorgan and Heiqia.

(2) PCA was used for the extraction of iron-staining anomalies from the high-fraction data (WorldView-2, IKONOS). The results indicated that the high-fraction data contained abundant information, high spatial resolution, good effect, and high accuracy of remote sensing anomalies extraction. Thus, it used to locate iron ore bodies worthy of extraction and has further applications.

(3) High-resolution remote sensing technology is suitable in iron ore geological and mineral remote sensing surveys and is similarly advantageous in both high-ground resolution of optical characteristics and particular spectral recognition capability. Moreover, it is effective not only for information extraction from a large area, but also for the recognition of local outcrops of mineralization. Therefore, it shouble be extended to other regions. The rapidly developing remote sensing technology, coupled with the successful launch of domestic high-resolution and hyperspectral satellites, is expected to provide a prospecting effect and wider application prospects for the improved exploration of mineral resources.

\section{ACKNOWLEDGEMENT}

This paper is supported by China's Geological Survey Project "Remote sensing geological survey of mineral resources in the West Kunlun Metallogenic Belt" (No. 1212011120888), Remote sensing interpretation and application of resources and environment satellite in "one belt and one road" (No.DD20160117), and National key basic research program of "973" project "Sedimentary environment and large-scale mineralization in continental basin of giant sandstone uranium metallogenic belt in North of China" (2015CB453000). Thanks to the anonymous reviewers and editors of TEA FLUKSI, LIDIJA GALOVIĆ and JULIE ROBSON for their suggestions on the paper.

\section{REFERENCES}

ALIJAGIĆ, J. \& ŠAJN, R. (2020): Application and improvement of soil spatial distribution mapping using advanced modelling techniques.- Geologia Croatica, 73/1, 69-84. doi: $10.4154 / \mathrm{gc} .2020 .01$

BUREAU OF GEOLOGY AND MINERAL RESOURCES OF XINJIANG AUTONOMOUS REGION (1993): Regional geology of Xinjiang autonomous region.-Beijing: Geological Publishing House, 1-841 (in Chinese).

CHEN, L., ZHANG, W., ZHOU, Y., LIU, W. \& CHEN, W. (2012): Application of highresolution remote sensing images to searching for sedimentary-metamorphic type iron deposits in the Taxkorgan area, Xinjiang.- Geology and Exploration, 48/5, 1039-1048 (in Chinese with English abstract).

CHEN, S.J., LI, R.S., JI, W.H., ZHAO, Z.M., MENG, Y. \& SHI, B.D. (2007): The deposition characteristics and tectono-plaeogeographic environment of Kunlun orogenic belt in late Devonian.- Geotectonicaet Metallogenia, 31/1, 44-51. (in Chinese with English abstract).

CHENG, Y.Q. (1994): Outline to the regional geology of China.- Beijing: Geological Publishing House, 1-200 (in Chinese).

CUI, J.T., BIAN, X.W., WANG, J.C., YANG, K.J., ZHU, H.P. \& ZHANG, J.L. (2006): Discovery of an unconformity between the Lower Silurian and Middle Devonian in the Tianshuihu area, southern Kangxiwar, West Kunlun, China.- Geological Bulletin of China, 25/12, 1437-1440 (in Chinese with English abstract).

DONG, Y.G., GUO, K.Y., XIAO, H.L., ZHANG, C.L., WANG, A.G. \& ZHAO, Y. (2003): Ore prospects of the West Kunlun area in western China.- Geology in China, 30/2, 173-178 (in Chinese with English abstract).

FAN, Y., WANG, H., YANG, X., LIANG, M., PAN, C., ZHANG, S., WANG, W. \& TAN, F. (2021): Application of airborne hyper-spectral survey system CASI/SASI in the gold-silver-lead-zinc ore district of Huaniushan, Gansu, China.- Geologia Croatica, 74/1, 73-83, doi: 10.4154/gc.2021.04.

FENG, C.R., WU, H. C. \& CHEN, Y. (2011): Geological characteristics and genesis of the Zankan iron deposit in Taxkorgan, Xinjiang.- Geotectonica Et Metallogenia, $35 / 3,404-409$.

GAO, X.F., XIAO, P.X., KANG, L., ZHU, H.P., GUO, L., XI, R. G. \& DONG, Z.C. (2013): Origin of the volcanic rocks from the Ta'axi region, Taxkorgan, Xinjiang and its geological significance.- Earth Science - Journal of China University of Geosciences, 38/06, 1169-1182 (in Chinese with English abstract).

GARAŠIĆ, V. \& JURKOVIĆ, I. (2012): Geochemical characteristics of different iron ore types from the Southern Tomašica deposit, Ljubija, NW Bosnia.- Geologia Croatica, 65/2, 255-270. doi: 104154/gc.2012.16

GENG, X.X.,YANG, J.M., ZHANG, Y.J. \& YAO, F.J.(2008): The application of ASTER remote sensing data for extraction of alteration anomalies information in shallow overburden area - a case study of the Baoguto porphyry copper deposit intrusion in Western Junggar,Xinjiang.- Geological Review, 54/2, 184-191. doi: 10.16509/j. georeview. 2008.02.015.

HOU, Q., MOU, C., WANG, Q. \& TAN, Z. (2018): Provenance and tectonic setting of the Early and Middle Devonian Xueshan Formation, the North Qilian Belt, China.Geological Journal, 53, 1404-1422. doi: 10.1002/gj.2963

HOU, Z.Q., SONG, Y.C., LI, Z., WANG, Z.L., YANG, Z.M., YANG, Z.S., LIU, Y.C., TIAN, S.H., HE, L.Q., CHEN, K.X., WANG, F.C., ZHAO, C.X., XUE, W.W. \& LU, H.F. (2008): Thrust-controlled sediments-hosted $\mathrm{Pb}-\mathrm{Zn}-\mathrm{Ag}-\mathrm{Cu}$ deposits in ASTER and northern margins of Tibetan orogenic belt: Geological features and tectonic model.- Mineral Deposits, 27/2, 123-144 (in Chinese with English abstract).

HOWARI, F.M., AYDAROOS, F.A., NAZZAL, Y., IQBAL, J. \& BOU ORM, N. (2019): Hyperspectroscopic and microtopographic analysesof salt crust forms on arid, silty clay loam desert soils.- Geologia Croatica., 72/1, 43-49. doi: 10.4154/gc.2019.01

JELENKOVIĆ, R., MILOVANOVIĆ, D., KOŽELJ, D. \& BANJEŠEVIĆ, M. (2016): The Mineral Resources of the Bor Metallogenic Zone: A Review.- Geologia Croatica, 69/1, 143-155. doi: 10.4154/gc.2016.11

JIA, Q. (1999): Massive Sulfide Copper Deposits of West Kunlun, Xinjiang.- Beijing: Geological Publishing House, 1-100 (in Chinese)

JIANG, C.F. (2002): Important geological problems and the research progress of the Central Orogenic Belt.- Regional Geology of China, 21/Z2, 453-455 (in Chinese with English abstract).

JIANG C.F. \& ZHU S.N. (1992): Introduction to tectonic migration theory.- Acta Geoscientica Sinica, 25, 1-14 (in Chinese with English abstract).

JIANG, C.F., YANG, J.S. \& FENG, B.G. (1992): Opening and closing structure of Kunlun.- Beijing: Geological Publishing House, 1992, 161-168 (in Chinese).

JIN, J., TIAN, S.F., JIAO, R.C. \& GAO, H. (2013): Lithology identification with WorldView-2 data based on spectral analysis of surface features: a case study of Wulukesayi district in Xinjiang.- Geoscience, 27/2, 489-496.

JIN, M.S., WANG, H., QIAO, G.B. \& ZHANG, S.P. (2014): The Discovery of Heiqia Iron Mineralization Belt in West Kunlun by High Resolution Remote Sensing Technology and Its Geological Significance.- Northwestern Geology, 47/4, 221-226 (in Chinese with English abstract).

JURKOVIĆ, I. \& HRVATOVIĆ, H. (2014): Geochemical characteristics and genesisof Mačje Jame and Vranjski Potok As-Cu-bearing iron occurrences westand southwest of the town of Busovača, Mid-Bosnian Schist Mountains (MBSM).- Geologia Croatica, 67/2, 145-161. doi: 10.4154/gc.2014.11

KANG, L., XIAO, P.X., GAO, X.F., XI, R.G. \& YANG, Z.C. (2015): Neopaleozoic and Mesozoic granitoid magmatism and tectonic evolution of the western West Kunlun Mountains.- Geology in China, 42/3, 533-552 (in Chinese with English abstract).

LI, B.Q., YAO, J.X., GAO, L.D., BIAN, X.W., YIN, Z.Y., CUI, J.T. \& CHEN, W.X. (2007): Age and source regions of the Wenquangou Group in the Mazhar-Kangxiwar area, West Kunlun Mountains.- Geological Bulletin of China, 26/4, 457-465 (in Chinese with English abstract).

LI, F.M., PEN, X.P. \& ZHANG, Q.J. (2010): Mineralization pattern and characteristics of Qirikeqi Siderite Deposit in West Kunlun.- Xinjiang Geology, 28/3, 274-279 (in Chinese with English abstract).

LI, T. \& WANG, Z.X. (2006): Transverse structure and model of fault slivers in the northern part of the Tarim block.- Geology in China, 33/1, 14-27 (in Chinese with English abstract).

LI, W., DONG, Y., GUO, A., LIU, X. \& ZHOU, D. (2013): Chronology and tectonic significance of Cenozoic faults in the Liupanshan Arcuate Tectonic Belt at the northeastern margin of the Qinghai-Tibet Plateau.- Journal of Asian Earth Sciences, 73, 103-113. doi: 10.1016/j.jseaes.2013.04.026

LI, W.Y. (2015): Metallogenic geological characteristics and newly discovered orebodies in Northwest China.- Geology in China, 42/3, 365-380 (in Chinese with English abstract).

LI, W.Y., ZHANG, Z.W. \& GAO, Y.B. (2008): The important mineralization events and tectonic response of Qinling, Qilian and Kunlun orogenic belts [C]//Chen Yuchuan, Xue Chunji, Zhang Changqing. Endeavoring Deep Marching West Scaning World -Symposium of the Ninth Mineral Deposit Conference in China.- Beijing: Geological Publishing House, 15-16 (in Chinese). 
LI, W.Y., ZHANG, Z.W., GAO, Y.B., TAN, W.J., JIANG, H.B. \& GUO, Z.P. (2011): Important metallogenic events and tectonic response of Qinling, Qilian and Kunlun orogenic belts.- Geology in China, 38/5, 41-50 (in Chinese with English abstract).

LIU, L., YA, B., LEI, LY. \& YANG, Q. (2015): Early Paleozoic granitic magmatism related to the processes from subduction to collision in South Altyn, NW China.Science China Earth Sciences, 58, 1513-1522. doi: 10.1007/s11430-015-5151-1

LU, S.N., LI, H.K. \& CHEN, Z.H. (2003): Characteristics, sequence and ages of Neoproterozoic thermo-tectonic events between Tarim and Yangzi blocks - A hypothesis of Yangzi - Tarim connection.- Earth Science Frontiers, 10/4, 321-326 (in Chinese with English abstract).

MENG, Y.K., XIONG, F.H., XU, Z.Q. \& MA, X.X. (2019): Petrogenesis of Late Cretaceous mafic enclaves and their host granites in the Nyemo region of southern Tibet: Implications for the tectonic-magmatic evolution of the Central Gangdese Belt.- Journal of Asian Earth Sciences, 176, 27-41. doi: 10.1016/j.jseaes.2019.01.041

PAN, Y.S. (1989): Tectonic division of Kunlun mountain.- Journal of Natural Resources, 4/3, 196-203 (in Chinese with English abstract).

PAN, Y.S. (1994): The discovery and demonstration of the fifth suture zone in QinghaiTibet Plateau.- Chinese Journal of Geophysics, 37/2, 184-192 (in Chinese with English abstract).

PAN, Y.S. (1999): The formation and uplifting of the Qinghai Tibet Plateau.- Earth Science Frontiers, 6/3, 153-163 (in Chinese with English abstract).

PAN, Y., YI, W., MATTE, P. \& TAPPONNIER, P. (1995): Geology Along the Line from Yecheng to Shiquanhe and Tectonic Evolution of the Region Involved.- Acta Geologica Sinica, 8/2, 119-133.

PAN, Y.S., ZHOU, W.M., XU, R.H., WANG, A.D., ZHANG, Y.Q., XIE, Y.W., CHEN, T.E. \& LUO, H. (1996): Early Paleozoic geological features and evolution of the Kunlun Mountains.- Science in China (Ser. D), 26/4, 302-307 (in Chinese)

QIAO, G.B., WANG, P., WANG, Z.H., WU, Y.Z., WU, H.C., ZHAO, X.J. \& CHEN, D.H. (2016): Genesis of the Qieliekeqi Iron Deposit in Western Kunlun: Evidence from Geological and Geochemical Characteristics.-Acta Geologica Sinica, 90/10, 2830-2846

QIAO, G.B., WANG, P., WU, Y.Z., HAO, Y.H., ZHAO, X.J., CHEN, D.H., LU, P.R. \& DU, W. (2015): Formation age of ore-bearing strata of the Zankan iron deposit in Taxkorgan landmass of Western Kunlun Mountains and its geological significance-- Geology in China, 42/3, 616-630 (in Chinese with English abstract)

QIN, Y., FENG, Q., CHEN, G., CHEN, Y. \& ZOU, K. (2018): Devonian post-orogenic extension-related volcano-sedimentary rocks in the northern margin of the Tibetan Plateau, NW China: Implications for the Paleozoic tectonic transition in the North Qaidam Orogen.- Journal of Asian Earth Sciences, 156, 145-166. doi: 10.1016/j.jseaes.2018.01.009

SHANG, D. (2009): WorldView-2 high resolution satellite launch successfully.- Remote Sensing For Land \& Resources, 20/4, 109 (in Chinese).

SUN, H.T., LI, C.J., LI, J.R. \& WU, H. (1997): The ore-forming prospecting of copper deposit in Kungaishan area of west Kunlun, Xinjiang.- Geology in China, 24, 29-30 (in Chinese with English abstract).

WAND, J.F. (2013): Remote sensing study of metallogenic condition in West Kunlun Laobing-Zankan ore concentration area.- Northwestern Geology, 46/2, 167-173.

WANG, C., LIU, A., WANG, H., HE, SP., LI, P. \& RONG, Y. (2015): Recognition and tectonic implications of an extensive Neoproterozoic volcano-sedimentary rift basin along the southwestern margin of the Tarim Craton, northwestern China.- Precambrian Research, 257, 65-82. doi: 10.1016/j.precamres.2014.11.022

WANG, C., LIU, L., KORHONEN, FAWNA, YANG, W. \& CAO, Y. (2016): Origins of Early Mesozoic granitoids and their enclaves from West Kunlun, NW China: implications for evolving magmatism related to closure of the Paleo-Tethys ocean.International Journal of Earth Sciences, 105, 941-964. doi: 10.1007/s00531-015$1220-0$

WANG, H., FAN, Y. H., YANG, J.Z., ZHANG, S.P., JIN, M.S., YANG, C., LIANG, M., CUI, S., HE, X.L. \& PAN, C.J. (2017): The application of high resolution remote sensing technology in the iron ore of Taxkorgan area, West Kunlun Mountains.Northwestern Geology, 50/2, 231-243 (in Chinese with English abstract).

WANG, H., FAN, Y.H., ZHANG, S.P., JING, M.S., CUI S., WANG, W.B., YANG, C., KUANG, J.S. \& GUO P.C. (2016): Delineation of Heiqiairon polymetallic mineralization zone in West Kunlun region by using high resolution remote sensing technology.- Geological Survey of China, 3/5, 13-20 (in Chinese with English abstract).

WANG, R.S., XIONG, S.Q., NIE, H.F., LIANG, S.N., QI, Z.R., YANG, J.Z., YAN, B.K., ZHAO, F.Y., FAN, J.H., GE, D.Q., ZHANG, X.K., ZHANG, Z.H., WANG, P.Q., GUO, X.F. \& LI, L. (2011): Remote Sensing Technology and its Application in
Geological Exploration.- Acta Geologica Sinica, 85/11, 1699-1742 (in Chinese with English abstract).

WANG, S.L., WANG, D.B. \& ZHU, X.Y. (2000): Ore-searching prospecting analysis of gold(copper) deposits in the West Kunlun.- Contribution to Geology and Mineral Resources Research, 15/3, 224-229 (in Chinese with English abstract).

WANG, X., ZHANG, X., GAO, J., LI, J. \& JIANG, T. (2018): A slab break-off model for the submarine volcanic-hosted iron mineralization in the Chinese Western Tianshan: Insights from Paleozoic subduction-related to post-collisional magmatism.Ore Geology Reviews, 92, 144-160. doi: 10.1016/j.oregeorev.2017.11.015

WANG, Y., LI, D.G., XIAO, X.C., CHI, Z.Q., MIN, L.R., WANG, J. \& WANG, Y.B. (2006): Late Cenozoic tectonic movement in the front of the West Kunlun Mountains and uplift of the northwestern margin of the Qinghai- Tibetan Plateau.- Geology in China, 33/1, 41-47 (in Chinese with English abstract).

WANG, Z., WANG, J., DU, Q., DENG, Q. \& YANG, F. (2013): The evolution of the Central Yangtze Block during early Neoarchean time: Evidence from geochronology and geochemistry.- Journal of Asian Earth Sciences, 77, 31-44. doi: 10.1016/j. jseaes.2013.08.013

WU, J.H. \& LIU, S.A. (2008): Introduction to geotectonics and outline of Chinese Earth Tectonics.- Beijing: Geological Publishing House (in Chinese).

XI'AN INSTITUTE OF GEOLOGY AND MINERAL RESOURCES (2006): The Prospecting Potential of Mineral Resources in Northwest China.- Beijing: Geological Publishing House, 1-150 (in Chinese).

XU, Z.Q., QI, X.X., LIU, F.L., YANG, J.S., WU, C.L., ZENG, L.S. \& LIANG, F.G. (2004): The Kangxiwar Caledonian Khondalite series in West Kunlun, China, and its geological significance.- Acta Geologica Sinica, 78/6, 733-743 (in Chinese with English abstract)

YAN, C.H., CHEN, C.J. \& CAO, X.Z. (2012): The discovery of the "Pamir-type" iron deposits in Taxkorgan area of Xinjiang and its geological significance.- Geological Bulletin of China, 31/4, 549-557.

YANG, J.S., WANG, X.B., SHI, R.D., XU, Z.Q. \& WU, C.L. (2004): The Dur'ngoi ophiolite in East Kunlun, northern Qinghai - Tibet Plateau: a fragment of paleo - Tethyan oceanic crust.- Geology in China, 31/3, 225-239 (in Chinese with English abstract)

YANG, J.Z. \& ZHAO, Y.L. (2015): Technical features of remote sensing and its application in the geological survey and mineral resources survey.- Mineral Exploration, 6/5, 529-534 (in Chinese with English abstract).

YANG, J.Z., FANG, H.B., ZHANG, Y.J. \& CHEN, W. (2003): Remote sensing anomaly extraction in important metallogenic belts of western China.- Remote Sensing for Land and Resources, 15/3, 50-53 (in Chinese with English abstract).

YANG, K.N. (1994): Tectonic evolution of continental margin on the West Kunlun and type of southwestern Tarim Basin.- Geological Review, 1, 9-18 (in Chinese with English abstract)

YAO, J.X., XIAO, X.C., GAO, L.D., HAN, F.L., CUI, J.T., PENG, H.L., JI, Z.S. \& WU, C.C. (2006): Silurian acritarchs and chitinozoans in Wenquangou Group from The West Kunlun region.- Acta Palaeontologica Sinica, 45/4, 528- 532 (in Chinese with English abstract).

YUN, J., GAO, X.F., XIAO, P.X., KANG, L. \& LI, P. (2015): Geochemical characteristics of the Lower Carboniferous volcanic rocks of the Wuluate Formation in the Western Kunlun Mountains and their geological significance.--Geology in China, 42/3, 587-600 (in Chinese with English abstract).

ZHANG, C., PENG, L.H., WANG, B., ZHANG, E., FU, L.H., WEI, B.Z. \& JIE, W.H. (2015): Application of WorldView-2 remote sensing image in the exploration of the volcano-sedimentary metamorphic type iron deposits in the Dimunalike area, Xinjiang.- Mineral Exploration, 6/5, 523-528 (in Chinese with English abstract).

ZHANG, Y.J., YANG, J.M. \& YAO, F.J. (2006): The extraction of OHA from different types of deposits by using ASTER data.- Mineral Deposits, 25 (Supplement), 507-510.

ZHAO, G., YIN, C., GUO, J., SUN, C., SUN, Z. \& LI, S. (2010): Metamorphism of the Luliang amphibolite: implications for the tectonic evolution of the north China craton.- American Journal of Science, 310, 1480-1502. doi: 10.2475/10.2010.10

ZHAO, J.A. \& LIU, Z.J. (2014): Mesoproterozoic Pashtok dioriteintrusive sequenceon the northern margin of West Kunlun orogenic belt in Xinj fang and its geological implications.- Geology in China, 41/1, 92-107 (in Chinese with English abstract).

ZHU, L.J., QIN, Q.M. \& CHEN, S.J. (2003): The reading of ASTER data form file and the application of ASTER data.- Remote Sensing for Land \& Resources, 56/2, 59-63.

ZONG, W.M., GAO, L.Z., DING, X.Z. \& PANG, W.H. (2010): Characteristics of Nanhuan Diamictite (Tillite) and Stratigraphic Correlation in the Southwestern Margin of Tarim Basin.- Geology in China, 37/4, 1183-1190 (in Chinese with English abstract). 

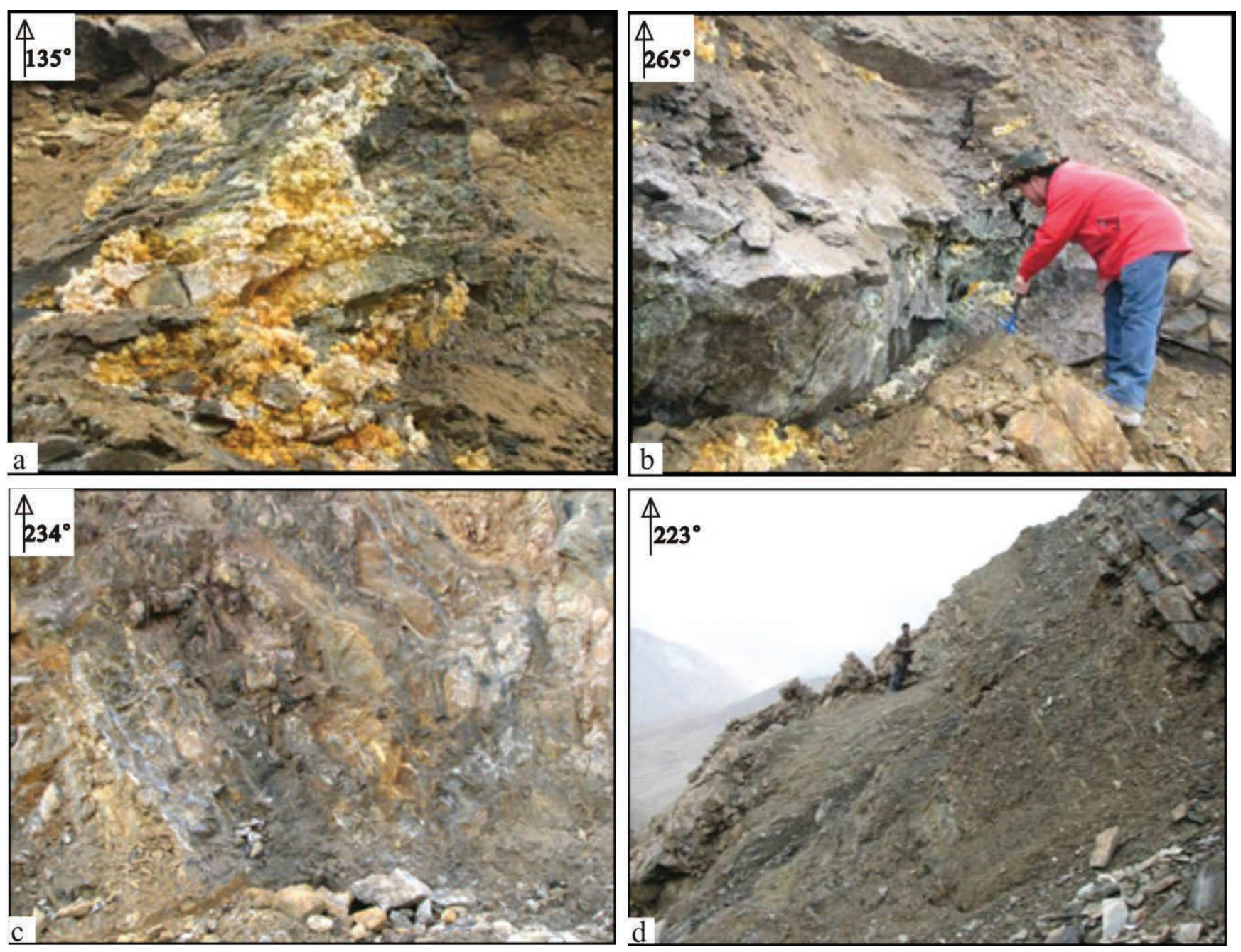

Plate 1. Field photography of the iron ore belt in Taxkorgan.

a jarosite on the surface of the Zankan iron ore body;

b Zankan iron ore body outcrop;

c Laobing iron ore body outcrop and

d Yerite Valley iron ore body outcrop. 

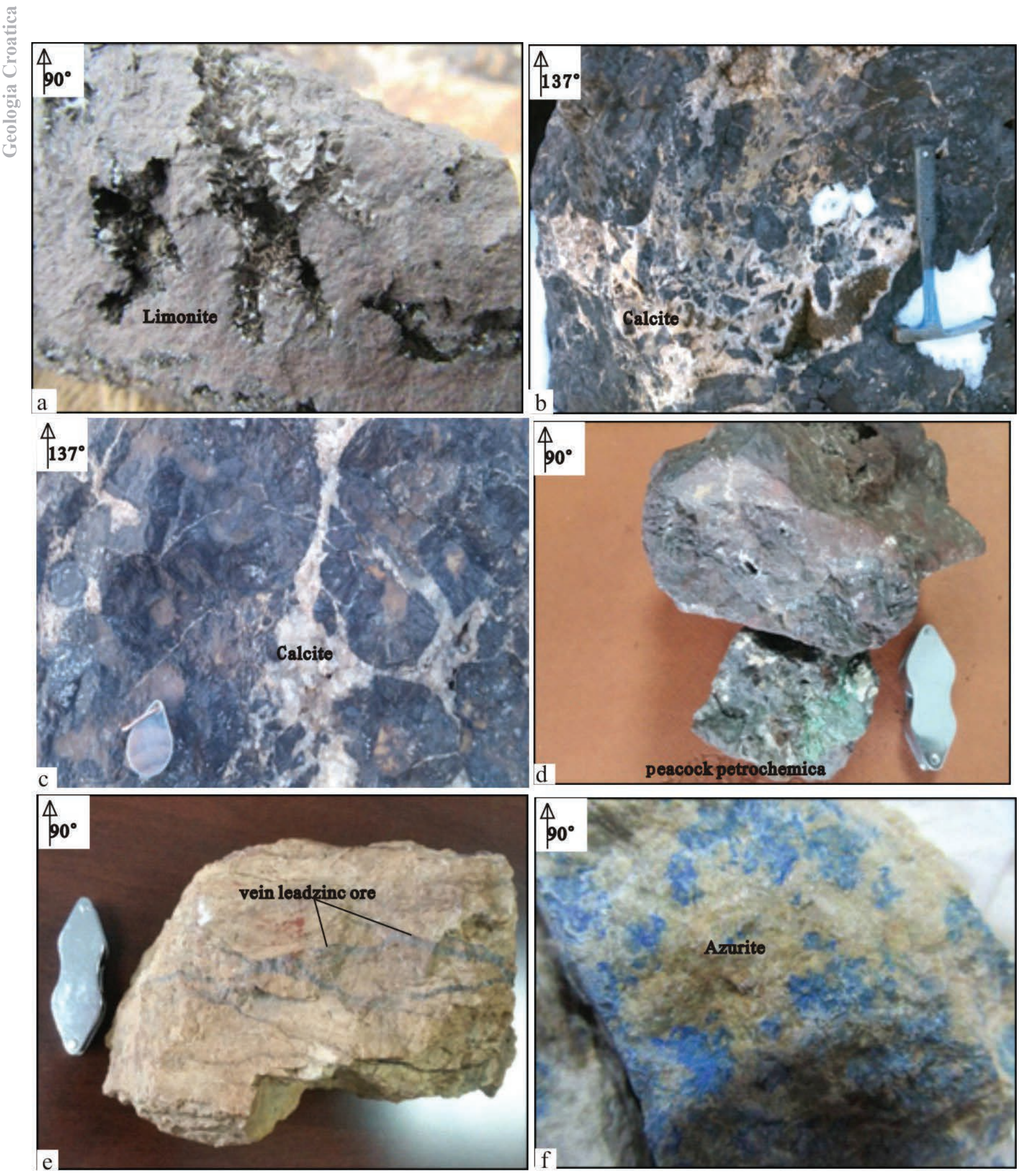

Plate 2. Field photography of the ore in Heiqia.

a massive and honeycombed limonite;

b breccia limonite;

c concretion forms limonite;

d lead mineralization and malachite mineralization of ore;

e vein lead-zinc ore in roof of iron ore and

$f$ azurite in marbleization dolomite of iron ore. 